\title{
Methodology of Analysing Geodetic Network as Basis for Developing Mobile Application for Its Ongoing Update
}

\author{
Anna Przewięźlikowska ( $\sim$ przewie@agh.edu.pl) \\ AGH University of Science and Technology \\ Wioletta Ślusarczyk \\ AGH University of Science and Technology \\ Klaudia Wójcik \\ AGH University of Science and Technology
}

\section{Research Article}

Keywords: Android applications, Java, Geodetic (surveying) technologies, geodetic control network, vertical control points, benchmark

Posted Date: October 14th, 2021

DOl: https://doi.org/10.21203/rs.3.rs-959391/v1

License: (c) (1) This work is licensed under a Creative Commons Attribution 4.0 International License. Read Full License 


\section{Abstract}

The final result of surveys largely depends on the accuracy and timeliness of the control network. This research paper presents the relationship between the condition of the points and the area where they are located. The main goal of this study is to present the methodology of a detailed analysis of the database of vertical control points in a selected area that is used to develop a mobile application intended for the update of the existing set of points of the vertical control network on an ongoing basis. In order to prepare the mobile application for the ongoing update of the control network, it is necessary to define detailed procedures for dealing with the database of points. These procedures concern the determination of the methodology of making an inventory of the existing database, and then the determination of the rules for updating the control network using the developed application.

\section{Introduction}

In today's world, universal access to mobile devices and the Internet affects the activities performed by every human being. Freely accessible applications cover the areas of entertainment, everyday life as well as more serious ones that are a source of information for analysis and research. Most applications enable users to collect various types of information which together form a content-rich database. This method should also be used in land surveying, where words such as data, database or ongoing update give rise to numerous ideas for their use.

Surveyors, while performing geodetic works, spend a large part of their time on the appropriate processing of the captured data and verification of their correctness and validity. This is pointed out in their papers [Mrówczyńska, Sztubecki, Greinert 2020], [Przewięźlikowska 2020], [Krzyżek, Przewięźlikowska 2017] and [Maciuk, Pęska-Siwik, El-Mowafy, Borowski, Apollo 2021]. For this reason, any form of assistance that speeds up this process and provides the possibility of preliminary verification of relevant information is a great help in their work.

Some of the control network points are difficult to access because the their establishment is based more on the quality of geodetic controls, reliability, geometrical strength, as well as cost rather than their topographic location [Bielecka, Pokonieczny, Kamiński, 2014]. Narrowing down the scope of works that a land surveyor deals with on a daily basis, the points of the geodetic control network are a very important element. Their accuracy to a large extent determines the final result of the performed surveys, which was presented in [Medved, Kuhar, Koler 2018]. Therefore, the timeliness of information on the actual status of the control network in the field is an important issue because, at the planning stage of their work, surveyors have the opportunity to select an undamaged point in the most convenient location.

There are many applications in land surveying that facilitate the surveyor's work, but they do not concern the geodetic control network that would be updated on an ongoing basis. The mere possession of a point database is not sufficient for the application to be useful. It is necessary to update the database on an ongoing basis because the condition of the control network changes for many reasons. It is problematic and costly for such a database to be maintained only by a specific group of people or an organisation. Hence, many publications e.g. [Brovelli, Minghini, Zamboni 2016] propose systems allowing for public participation in data capture. This specific publication analyses three different systems that allow users to access and modify spatial data using mobile devices. Where such initiatives were targeted at a large number of people, they were not very successful, but when initiatives were targeted at a specific group of people, the results were good. Therefore, an application aimed specifically at surveyors may prove successful.

A similar approach is described in the publication [Ell et al., 2018], which presents a mobile application for Android that allows to capture data and participate in surveys using similar devices. A slightly different approach was used by the authors of the ARGeo application, as described in [Gazcón, Trippel Nagel, Bjerg, Castro 2018], for field data capture. In this particular case, it is aimed at geologists. It allows to capture and analyse data using mobile devices. An unusual approach, however, is to enable work even without an Internet connection. The authors have rightly noticed that in some hard-to-reach places, an application that requires a permanent connection to the Internet can significantly hinder work, especially when the point is located in an area with poor mobile network coverage. 
The conducted research studies on the assessment of the condition and development forecast of the basic vertical, gravimetric and magnetic control networks [Graszka, Pielasa, Piętka, Wajda 2016], revealed that about $23 \%$ of benchmarks of the basic vertical control network covered by the surveys were destroyed.

The condition of the vertical control points may be influenced by external factors. These include e.g. environmental impacts that affect the subsidence of vertical control points. Considerations on this subject can be found in the research paper [Borowski, Lal, Nepelski 2017], where the earth marks of the vertical control network were selected for the analysis, as well as in the paper on the implementation of the research programme, which concerned the determination of the operational reliability of the vertical control network [Wolski, Derezińska 2008]. An important contribution for the presented subject describing the status of geodetic network is the publication [Banasik, Ligas, Kudrys, Skorupa, Bujakowski 2012].

\subsection{Existing applications for the location of geodetic points}

In Poland, there are information portals and applications that enable the presentation of control points on a map. The basic application for publicly available data presentation is the Geoportal, which is available in the following versions:

- mobile application for Android, iOS and Windows [GEOPORTAL - Mobile applications, 2020],

- internet application [GEOPORTAL 2 Maps, 2020].

This applies to the first-order and second-order control networks in a manner generally available to any user. This application allows to search for many important collections and services of spatial data essential for land surveying [GEOPORTAL - Mobile applications, 2020]. It is important that the Geoportal contains a layer with data regarding the basic vertical control network. Files in the .xls format are downloaded together with a folder containing topographic descriptions of points (Fig. 1).

However, attention should be paid to the fact that the Geoportal does not contain the control network most frequently used by surveyors, namely the third-order control network. Updating the information about this group of the networks and making it accessible is especially important for surveyors. This specific control network is used for all assortments of works, as presented in [Krzyżek, Uchański, Falkowski 2017]. The access and the appropriate quality of the control network result in accuracy of all the surveys performed, including record-keeping [Hanus, Pęska-Siwik, Benduch, Szewczyk 2020]. Therefore, this research paper proposes a methodology to develop an important and easy-to-use real-time information update application - Metrica (Fig. 2).

The second group of information systems are "Surveyor's portals" used exclusively by surveyors, only after authentication. The most commonly used control, namely the third-order control, can be obtained on various surveyor's portals.

The first and second groups include information portals that are used to share centrally or locally collected data to appropriate groups of recipients. At the same time, they are periodically updated in terms of the control network, based on procedures related to the modernisation of the control network. The last periodic review of level 1 and level 2 geodetic network was conducted at the request of Polish Main Geodetic Office (GUGiK) in 2019. Because of overlapping timing the article presented in [URL 14] did not yet include the data from the 2019 review.

The third group of applications includes those used to present data after appropriate import, such as Google Earth. In such a system, surveyors can only display what they receive from the ZGiK. Google Earth is available in three versions:

- mobile application for Android or iOS,

- website,

- computer application for PC, Mac and computers with Linux system.

This programme also allows to import files with point coordinates, which was used in this analysis to display points on the map and compare their actual location in the field with the graphic part of topographic descriptions [Google Earth 2020]. However, these applications are not intended to jointly update the presented data. 
The key group today should include mobile applications that enable displaying or searching for geodetic points and adding them. Examples of such applications are: Asystent Geodety [URL 2], MERGDATA survey [URL 3], GIS Mobile Applications [URL 4], Locus GIS - offline geodata collecting, SHP edits [URL 5]. For example, the "Asystent Geodety" application available on the Polish market is a mobile application for Android, dedicated to users working in the fields of: land surveying, geology, cartography, forestry and many others in which location plays an important role. In the free version it is available with limited options. In order to have full access to the services offered, it is necessary to purchase a premium package. This programme can be called a mobile position recorder, because it quickly determines the location of the client thanks to the built-in GPS module. The accuracy with which calculations are made and the operation of the GPS module is directly dependent on the hardware used to operate the programme [URL 2]. The application collects data in the following coordinate systems: PUWG 2000, PUWG 1965, 1942, PUWG 1992, BL Kras. and BL WGS84. The built-in calculator allows to convert coordinates between the supported systems. Adding new points is possible by importing data from a common .txt file or by manually entering the coordinates. Using the GPS function, there is also an option to add a point at the current location. The programme has a length measurement function for any polygonal chain that passes through the selected points, and a measurement of the area of any polygon [URL 2]. Despite the wide scope of application, this application lacks functions that would allow the surveyor to update and collect information about points on an ongoing basis. It is not possible to create a database of points that would be publicly available. Only points with given coordinates are stored there.

The main goal of this study is to present the methodology of a detailed analysis of the database of vertical control points in the selected area, which is to be used to develop a mobile application intended for the ongoing update of the existing set of vertical control points, downloaded from the Geodetic and Cartographic Documentation Resource (ZGiK). The developed application would aim to keep up-to-date information about a given vertical control point as well as to locate these points faster and more precisely in the field.

\section{Materials And Methods}

To design the application, a database of points for the selected area was retrieved from ZGiK to verify the status of these points in the field and to check the rationale for its development. Collecting the necessary information about the geodetic network had the fundamental importance for determining the optimum procedures for information updates with the help of the proposed application. Firstly, an analysis was conducted on how the location of points in different areas influences their actual maintenance status and its currency. The first factor was the division of the analysed control network with regard to its location. For this purpose, the following point location zones were distinguished:

- CC - City Centre

- CCO - City Centre Outskirts,

- T- Town,

- RA - Rural Area.

\subsection{Geodetic network}

Pursuant to Article 2.4 of [PGiK 1989], the geodetic control network is understood as systematic collections of clearly identifiable points that have been marked in the field with survey markers and whose location has been determined in the national spatial reference system in a manner appropriate for a given the type of the control network and enabling its accuracy to be determined.

The geodetic network includes points of the vertical control, the location of which has been determined in the national spatial reference system, and the height determined in relation to the adopted reference area, using surveying techniques [Regulation 2012]. Due to the important function of survey markers, they are protected by law. Persons who are owners or holders of real estate on which survey markers are located as well as triangulation structures or facilities protecting them, are obliged to:

- avoid actions that could damage, destroy or displace these markers, 
- report information on their damage, destruction, displacement or endangering the life or property of other people to the competent district governor.

Failure to comply with the above-mentioned obligations may result in imposition of a fine [PGiK 1989].

The numeration of geodetic network is uniform throughout the country. The numbers of the control points are assigned at the stage when the technical design is prepared, therefore in accordance with the law in force at the time. The current rules for the numeration of geodetic, gravimetric and magnetic control points have been regulated by the provisions of Chapter 9 [Regulation 2012]. However, the numeration of the points of the basic vertical control network analysed in the selected area was prepared at the time of validity of the Technical Guideline G-2 - Vertical Control Network [URL 6]. It should be noted that in the lists from the ZGiK database (Fig. 3) concerning control points, two concepts appear simultaneously: point number and point identifier.

The rules for creating a point identifier are defined in detail in [URL 7]. The point identifier consists of a string of thirteen digits. This system is closely related to the position of the point, determined by the $B, L$ geodetic coordinates.

\subsection{Vertical geodetic network database}

Pursuant to $\S 16$ and 17 [Regulation 2012], information about the points of the national geodetic network is collected in two sets:

- in the database of the national register of basic geodetic, gravimetric and magnetic control networks - GUGiK,

- in the database of the third-order geodetic control networks - PODGiK.

The State Register of Basic Geodetic Control Networks collects observations and the results of their elaboration for basic geodetic, gravimetric and magnetic control networks throughout the country [GEOPORTAL - basic control networks, 2020]. The current statistical data on the number of points in each type of the control network are presented in figure 4 . The chart illustrates the vertical control network, analysed in this study.

Source [GEOPORTAL - basic control networks, 2020]

\subsection{Preparation of the database of points used to create the application}

In order to prepare the mobile application for the current update of the network, it was necessary to define detailed procedures for dealing with the point database. These procedures initially involved defining the methodology of making an inventory of the existing database, and then the determination of the rules for updating the control network using the developed application. To confirm the research thesis regarding the timeliness of the data on the control network and to state the validity of creating the application, the database of basic vertical control points was used as a research object, covering a part of the Małopolskie Province in the vicinity of the city of Krakow (Fig. 5).

The database consisted of 799 points for which the following information was retrieved:

- $B, L$ coordinates in the PL-ETRF89-GRS80 system,

- normal height PL-KRON86-NH,

- point location address,

- point ID,

- point number in the "1965" system,

- control network order,

- monumentation code,

- information about the condition of the point.

153 points were selected for the analysis from the obtained database. Their choice was based on a selection aimed at distinguishing different types of locations (Fig. 6):

Page 5/29 
- CC - City Centre

- CCO - City Centre Outskirts,

- T - Town,

- RA - Rural Area.

A research hypothesis was formulated that the type of point location affects the quality of information about points and their timeliness. The decisive factors are the degree of urbanisation and the level of human interference with the surroundings (the environment). This assumption was intended to analyse to what extent these factors affect the control network to be maintained in an appropriate condition and timeliness. The designed types of locations were intended to indicate to what extent location factors determine:

- point database completeness (the number of points actually existing),

- accessibility of measurement points,

- timeliness of information about points,

- examination of the technical condition of the points.

\subsection{Characteristics of location types}

As the City Centre (CC) and City Centre Outskirts (CCO) the authors chose Krakow which is:

- the capital of Małopolskie Province,

- the largest city in the province,

- the city with provincial rights

is the City Centre (Fig. 6). The city's infrastructure is highly developed, with dominant dense development.

The control points selected for the analysis, located in the strict city centre, are within the limits of the CC and CCO point location zones, which have been determined by circles with a given diameter:

- CC - 3 km (marked in red),

- CCO - 5 km (marked in yellow),

whose starting point is in the centre of the Main Square.

For the CC zone, 44 points were analysed, i.e. all occurring in this area, the distribution of which is illustrated in (Fig. 6). All points were within a predetermined circle with a radius of $3 \mathrm{~km}$.

The area encompassing CCO contained 53 points of the basic second-order control network and all of them were analysed. The points were evenly distributed around the CC zone, in a strip formed by circles with radii of 3 to $5 \mathrm{~km}$ (Fig. 5).

Another point location zone created for the analysis is Towns (T) (Fig. 5). Two exemplary towns located south of Krakow were selected: Myślenice and Skawina. Myślenice is an urban-rural commune, which is the largest commune in terms of the area in Małopolska. The topography of the area is diversified and most of it remains undeveloped. There is only dense development in the very centre of the town [URL 8]. Considering the area and population, Myślenice is one of the smaller towns in Poland. The database in Myślenice consists of 14 points of the basic second-order vertical control network, all of which were analysed. Most of the points are located near main roads and in heavily urbanised places.

The second of the selected towns is Skawina. It is located in the Krakow county in the urban-rural commune of Skawina [URL 9]. The direction of the town's development in recent years has created favourable conditions for the growth of new investments. The rapid expansion of the town is favoured by:

- its convenient location (Krakow is about $17 \mathrm{~km}$ away), 
- a lot of unused land,

- developed industrial zones,

- extensive communication network,

- diverse labour market providing employment for many people.

In Skawina, 9 out of 10 existing points, which form the database of the basic second-order vertical control network, were selected for the analysis.

In addition to urban areas, 4 representative urban-rural communes located in rural areas (RA) were selected (Fig. 6):

- Czernichów,

- Liszki,

- Świątniki Górne,

- Wieliczka.

The selection was aimed at checking points in areas with lower investment development, where control points are less used. Out of 83 points from the database, 33 points of the basic second-order vertical control network located in rural areas (RA) in villages near a large city were selected for the analysis (Fig. 6). The points were selected with view to various degrees of the influence of external factors such as the immediate vicinity of a busy road, location on private properties, etc. Figure 6 illustrates the control points selected for the analysis in all the types of the areas presented.

Table 1 demonstrates the most important data characterising the individual communes selected for the analysis in terms of topography and geodesy.

Table 1. General information on selected communes.

Source [URL 10], [URL 11], [URL 12], [URL 13]

\begin{tabular}{|c|c|c|c|c|c|c|c|}
\hline & City & Town & & Rural Area & & & \\
\hline & KRAKOW & MYŚLENICE & SKAWINA & $\begin{array}{l}\text { COMMUNE } \\
\text { OF } \\
\text { CZERNICHÓW }\end{array}$ & $\begin{array}{l}\text { COMMUNE } \\
\text { OF LISZKI }\end{array}$ & $\begin{array}{l}\text { COMMUNE } \\
\text { OF } \\
\text { SWWIATNIKI } \\
\text { GORNE }\end{array}$ & $\begin{array}{l}\text { COMMUNE } \\
\text { OF } \\
\text { WIELICZKA }\end{array}$ \\
\hline $\begin{array}{l}\text { Area } \\
{\left[\mathrm{km}^{2}\right]}\end{array}$ & 327 & 30 & 21 & 84 & 72 & 20 & 100 \\
\hline Population & 774,389 & 18,415 & 243,25 & 14,712 & 17,447 & 10,195 & 60,481 \\
\hline $\begin{array}{l}\text { Altitude above sea } \\
\text { level [m] }\end{array}$ & $188-300$ & $315-648$ & 218 & $220-365$ & $212-246$ & $230-400$ & $222-362$ \\
\hline $\begin{array}{l}\text { Number of basic } \\
\text { vertical control } \\
\text { points }\end{array}$ & 279 & 14 & 10 & 17 & 7 & 10 & 49 \\
\hline $\begin{array}{l}\text { Point density } \\
\text { [points/km^2] }\end{array}$ & 0.85 & 0.47 & 0.47 & 0.20 & 0.10 & 0.50 & 0.49 \\
\hline
\end{tabular}

\subsection{Analysis of the condition of points in selected research areas}

The condition of the points was checked in several stages, based on a field inspection for the purpose of developing an application for updating geodetic network points. The prepared database of points was verified taking into account various criteria, defined by the authors. The adopted criteria of the analysis were related to the specificity of the available data on points. The sequence of the analysis of individual criteria was determined in detail therefrom. 
1. Existence of the control point in the ZGiK database - B, L coordinate data, point address, the point also accessible in [GEOPORTAL 2 Maps, 2020].

2. Accessibility of the point for inspection - an inaccessible point is the one located on the property inaccessible to entry - no further verification.

3. Occurrence of the point in the field - the point physically exists in the field.

4. Existence of topographic description of the point.

5. Consistency of the point location with the graphic part of the topographic description.

6. Consistency of the $B, L$ coordinates with the actual location of the point in the field - with the presentation in Google Earth concerns the consistency of the point location as indicated based on the coordinates retrieved from ZGiK, displayed using Google Earth with the actual location in the field. A significant deviation in the location of a given point, which could result in selecting an incorrect point or considering the point as non-existent, was considered an irregularity.

7. Possibility of performing surveys on the point - when it is possible to place the staff correctly on the point.

8. The point has been built-up - consequently, the survey is impossible.

9. The point has been destroyed.

In order to optimise the point analysis process, criteria were distinguished that could be analysed independently of each other, e.g. 6 and 7, as well as those whose analysis was justified only subject to prior verification of other criteria, e.g. criterion 3 depending on 7. Therefore, the above numeration of the criteria was given by topological sorting of the graph according to the order of their verification presented in the diagram (Fig. 7).

During the field inspection, various situations were encountered when the condition of control points was changing over time. One of the cases was when the point was built-up, which hindered the performance of surveys on that point. Such activities are the result of human ignorance about the way the control network is used. The direct analysis of the control network conducted in the field demonstrated to what extent the information on the points may be outdated. The comparison of the existing status with the information retrieved from ZGiK revealed that the main users of the network, i.e. surveyors, can be frequently misled. Due to the numerous irregularities identified in the status of information about the control network, it was decided to create a tool that would make it possible to update the information about control points on an ongoing basis. It seems that the best solution for such work is a mobile application which:

- would allow for the correct determination of the point location in the field,

- would enable real-time updating of the point information.

The diagram presented in figure 7 demonstrates the scope of the information on the control network that needs to be updated depending on the identified discrepancies in the existing information on the point. They can be divided into two main groups:

- update of outdated data - procedure A, B, C, F, G,

- update of non-existent data - procedure $D, E$.

In each of the groups of the necessary update, however, the scope of the data that needs to be completed is adapted to a specific case.

\section{Results And Discussion}

Having defined the research areas and having selected the control points for the direct analysis, the control network was verified in the field. This was a very important stage of the procedure, necessary for its correct analysis. The field inspection included the analysis of information about each point according to the previously defined 9 criteria:

1. Existence of the control point in the ZGiK database,

2. Accessibility of the point for inspection,

3. Occurrence of the point in the field, 
4. Existence of topographic description of the point,

5. Consistency of the point location with the graphic part of the topographic description,

6. Consistency of the $B, L$ coordinates with the actual location of the point in the field,

7. Possibility of performing surveys on the point,

8. The point has been built-up,

9. The point has been destroyed.

These criteria were analysed for each of the points in an appropriate order, resulting from the planned procedure (Fig. 7). The result of the conducted field inspection is the collected information presented in fragments in the exemplary Table 2.

Table 2. Criteria for analysis of control network in the field.

Source: Authors' original contribution

\begin{tabular}{|c|c|c|c|c|c|c|c|c|c|c|c|c|c|c|}
\hline \multicolumn{15}{|c|}{ City Centre Outskirts (COC) } \\
\hline L.p. & $\begin{array}{c}\text { Point } \\
\text { number }\end{array}$ & Latitude & Longitude & $\begin{array}{c}\text { Is the point } \\
\text { accessible } \\
\text { for } \\
\text { inspection? }\end{array}$ & $\begin{array}{c}\text { Does the } \\
\text { poiat exist } \\
\text { in the field? }\end{array}$ & $\begin{array}{c}\text { Is there } \\
\text { topographic } \\
\text { description of } \\
\text { the point? }\end{array}$ & $\begin{array}{l}\text { Is the location } \\
\text { cansistent tith } \\
\text { the graphic part } \\
\text { of the } \\
\text { topographic } \\
\text { description? }\end{array}$ & $\begin{array}{c}\text { Are the B, L } \\
\text { coordinates } \\
\text { consistent with } \\
\text { the actual } \\
\text { location of the } \\
\text { point in the } \\
\text { ficld? }\end{array}$ & $\begin{array}{l}\text { Is it } \\
\text { possible } \\
\text { to carry } \\
\text { out } \\
\text { sureys } \\
\text { on the } \\
\text { point? }\end{array}$ & $\begin{array}{c}\text { Is the } \\
\text { point } \\
\text { built-up? }\end{array}$ & $\begin{array}{c}\text { Is the } \\
\text { point } \\
\text { destrayed? }\end{array}$ & Point address & Date & Remarks \\
\hline 10 & 16330091 & $50^{\circ} 02^{4} 40,0^{\circ}$ & $19^{\circ} 58^{\prime} 22,5^{\prime \prime}$ & YES & No & YES & - & - & - & - & - & $\begin{array}{l}\text { Krakóów - } \\
\text { Podgürze, ul. } \\
\text { Szkhanska ar } 5\end{array}$ & 24082020 & $\begin{array}{c}\text { No point - } \\
\text { building } \\
\text { demolished. }\end{array}$ \\
\hline 11 & 16330092 & $50^{\circ} 02^{\prime} 58,5^{\prime \prime}$ & $\left|19^{\circ} 58^{\prime} 55,7^{\prime \prime}\right|$ & YES & No & YES & - & - & - & - & - & $\begin{array}{c}\text { Krakków - } \\
\text { Podgürze, ul. } \\
\text { Staczniowéów nr } \\
7\end{array}$ & 24082020 & No peint. \\
\hline 12 & 16330093 & $500^{\circ} 03^{*} 04,6^{\circ}$ & $19^{\circ} 59^{\prime} 25,3^{\prime \prime}$ & YES & YES & YES & YES & YES & YES & No & No & $\begin{array}{c}\text { Krakiów - } \\
\text { Plaszow, ul, } \\
\text { Kocykarsca nr } \\
33 \\
\end{array}$ & 24082020 & $\begin{array}{l}\text { The building of } \\
\text { the "KRAKUS" } \\
\text { hotel. }\end{array}$ \\
\hline 13 & 16330506 & $50^{\circ} 03^{\circ} 54,0^{\circ}$ & $\left|19^{\circ} 52^{\prime} 36,3^{\prime \prime}\right|$ & YES & No & YES & - & - & - & - & - & $\begin{array}{c}\text { Krikbów, ul. } \\
\text { Kroblowej } \\
\text { Jadwigi in } 246\end{array}$ & $25,08: 2020$ & $\begin{array}{l}\text { No point, building } \\
\text { after revovation. }\end{array}$ \\
\hline 14 & 16330507 & $\left|50^{\circ} 05^{\prime} 20,4^{\prime \prime}\right|$ & $\left|19^{\circ} 53^{\prime} 09,3^{\prime \prime}\right|$ & so & - & YES & - & - & - & - & - & $\begin{array}{c}\text { Kraków, ul } \\
\text { Radzikowskiego } \\
\text { nr } 176 \\
\end{array}$ & 2541882020 & \begin{tabular}{|c} 
The point is \\
inakessible, the \\
aren is fenced.
\end{tabular} \\
\hline 15 & 16330508 & $50^{\circ} 04^{\prime} 24,8$ & $19^{\circ} 53^{\prime} 29.8^{\prime \prime}$ & YES & No & YES & - & - & - & - & - & $\begin{array}{l}\text { Krakiów, ul. J. } \\
\text { Les ir } 235\end{array}$ & $25: 082020$ & $\begin{array}{l}\text { No point, building } \\
\text { after revavation. }\end{array}$ \\
\hline 16 & 16330509 & $50^{\circ} 04^{\prime} 08,6^{\prime \prime}$ & $19^{\circ} 52^{\prime} 32,4^{\prime \prime}$ & YES & YES & YES & YES & YES & No & YES & No & $\begin{array}{l}\text { Kraków, ul. } \\
\text { Jesionowa ns is }\end{array}$ & 250182020 & - \\
\hline 17 & 16330513 & $\left|50^{\circ} 04^{\prime} 25,3^{\prime \prime}\right|$ & $\left|19^{\circ} 53^{\prime \prime} 20.2^{\prime \prime}\right|$ & YES & YES & YES & YES & YES & No & YES & No & $\begin{array}{c}\text { Krakowiw, ul. } \\
\text { Whosciantiska ar } \\
\text { I8 }\end{array}$ & $2508 / 2020$ & - \\
\hline 18 & 16330517 & $50^{\circ} 04^{\prime} 15,3^{\prime \prime}$ & $19^{\circ} 52^{\prime} 46,5^{\prime \prime}$ & YES & YES & YES & YES & YES & YES & No & No & $\begin{array}{c}\text { Kraków, ul. } \\
\text { Hanernia nir } 39\end{array}$ & 259082020 & - \\
\hline 19 & 16340566 & $50^{\circ} 04^{\prime \prime} 19,5^{\prime \prime}$ & $\left|19^{\circ} 59^{\circ} 04.2^{n}\right|$ & YES & YES & YES & YES & YES & YES & No & No & $\begin{array}{c}\text { Kraków, Al. } \\
\text { Jana Pawid II nr } \\
38\end{array}$ & $25,98 / 2020$ & - \\
\hline
\end{tabular}

153 out of 799 points retrieved from ZGiK were analysed. They were located in separate areas, according to the adopted criteria. The summary of the number of the analysed points is contained in Table 3 and in the form of a pie chart (Figures 8 and 9).

Table 3. Results of field inspection conducted for selected database of points.

Source: Authors' original contribution 


\section{Zone NUMBER OF ALL POINTS FOR type SELECTED AREAS RETRIEVED FROM ZGIK DATABASE}

\section{NUMBER OF POINTS ADOPTED FOR ANALYSIS RETRIEVED FROM ZGiK DATABASE}

NUMBER OF POINTS FOUND

IN THE FIELD

\section{Ratio of points found to analysed}

[\%]

\section{City \\ Centre}

$$
\text { City }
$$

44

53

Centre

Outskirts

\begin{tabular}{l}
\hline Towns \\
\hline Rural \\
Areas
\end{tabular}

TOTAL 204

44

53
31

31
70.5

58.5

$23 \quad 10 \quad 43.5$

33

13

39.4

When summarising the obtained results regarding the occurrence of points in the field in individual point location zones (City Centre, City Centre Outskirts, Towns and Rural Areas), the following conclusions can be drawn (Fig. 9):

- the greatest number of points were found in the City Centre zone,

- the greatest number of non-existent points were in the Town zone,

- the greatest number of inaccessible (hard-to-reach) points for analysis were located in the Rural Area zone.

Comparing the area of the City zone divided into the City Centre CC and the City Centre Outskirts CCO, a large discrepancy in the number of inaccessible points should be noted. In the case of the City Centre Outskirts, this number reaches $13.2 \%$ and is much higher than the number of points inaccessible for analysis in the City Centre zone, where it is approximately $4.5 \%$. This is due to the fact that in the City Centre $\mathrm{CC}$, most of the points are located on the main streets on the front walls of tenement houses, thanks to which they are generally accessible. Moving towards the City Centre Outskirts zone, more and more points are located on buildings of single-family houses, which are often fenced. The same tendency can be noticed in other point location zones, such as Towns and Rural Areas, where most of the properties belong to private owners. Fences significantly limit access to control points, which in the case of vertical control networks must frequently be placed on buildings, i.e. on private land. These statistics would probably look different for the horizontal control network, the location of which is usually chosen outside the private area in order to increase its accessibility in the field.

Attention should be paid to the disproportions that occurred in the Towns zone. Taking into account the entire database for this area, an even distribution between the found and non-existent points is noticeable (Fig. 9). There were 5 non-existent points in the Towns zone database ( 1 was destroyed, 4 were not found), which were also marked in the Geoportal as "destroyed points". They were all located at the main roads. It can be assumed that this condition is related to road modernisation, during which points can be easily damaged or destroyed.

However, there are also points that were not found during the field inspection, and according to the Geoportal they are still in good condition! The largest number of such cases was recorded in Skawina (Towns point location zone). They are presented in Figure 10. Such points from the entire Towns zone database are contained in Table 4.

Table 4. Information on points presented in Figure 9 not updated in Geoportal, collected in the field. Source: Authors' original contribution 


\begin{tabular}{|c|c|c|c|c|c|c|c|c|}
\hline $\begin{array}{l}\text { Point } \\
\text { number }\end{array}$ & Latitude & Longitude & $\begin{array}{l}\text { Is the point } \\
\text { accessible } \\
\text { for } \\
\text { inspection? }\end{array}$ & $\begin{array}{l}\text { Does } \\
\text { the } \\
\text { point } \\
\text { exist } \\
\text { in the } \\
\text { field? }\end{array}$ & $\begin{array}{l}\text { Is there } \\
\text { topographic } \\
\text { description } \\
\text { of the } \\
\text { point? }\end{array}$ & Address & $\begin{array}{l}\text { Does the } \\
\text { point exist } \\
\text { in } \\
\text { Geoportal? }\end{array}$ & $\begin{array}{l}\text { Condition } \\
\text { of point } \\
\text { according } \\
\text { to } \\
\text { Geoportal }\end{array}$ \\
\hline 17330012 & $\begin{array}{l}49^{\circ} 50^{\prime} \\
02,1^{\prime \prime}\end{array}$ & $\begin{array}{l}19^{\circ} 56^{\prime} \\
11.0^{\prime \prime}\end{array}$ & YES & NO & YES & $\begin{array}{l}\text { Myślenice, } \\
\text { Królowej } \\
\text { Jadwigi F. P. W. } \\
\text { in the church } \\
\text { square from } \\
\text { Kilińskiego str. } \\
\text { side }\end{array}$ & YES & good \\
\hline 17310111 & $\begin{array}{l}49^{\circ} 58^{\prime} \\
21,0^{\prime \prime}\end{array}$ & $\begin{array}{l}19^{\circ} 48^{\prime} \\
26.1^{\prime \prime}\end{array}$ & YES & NO & YES & $\begin{array}{l}\text { Skawina, 11, } \\
\text { Piłsudskiego str. }\end{array}$ & YES & good \\
\hline 17310117 & $\begin{array}{l}49^{\circ} 58^{\prime} \\
40,7^{\prime \prime}\end{array}$ & $\begin{array}{l}19^{\circ} 49^{\prime} \\
12.3^{\prime \prime}\end{array}$ & YES & NO & YES & $\begin{array}{l}\text { Skawina, 13, } \\
\text { Tyniecka str. }\end{array}$ & YES & good \\
\hline 17310122 & $\begin{array}{l}49^{\circ} 58^{\prime} \\
38,2^{\prime \prime}\end{array}$ & $\begin{array}{l}19^{\circ} 49^{\prime} \\
58.0^{\prime \prime}\end{array}$ & YES & NO & YES & $\begin{array}{l}\text { Skawina, } 19 \\
\text { Krakowska str. }\end{array}$ & YES & good \\
\hline 17310212 & $\begin{array}{l}49^{\circ} 57^{\prime} \\
55,0^{\prime \prime}\end{array}$ & $\begin{array}{l}19^{\circ} 49^{\prime} \\
21.8^{\prime \prime}\end{array}$ & YES & NO & YES & $\begin{array}{l}\text { Skawina, 2, } \\
\text { Spacerowa str. }\end{array}$ & YES & good \\
\hline 17310200 & $\begin{array}{l}49^{\circ} 57^{\prime} \\
28,2^{\prime \prime}\end{array}$ & $\begin{array}{l}19^{\circ} 49^{\prime} \\
35.4^{\prime \prime}\end{array}$ & YES & NO & YES & $\begin{array}{l}\text { Skawina, } \\
\text { extension of } \\
\text { Dębca str. }\end{array}$ & YES & good \\
\hline
\end{tabular}

It is also worth mentioning that in addition to the point analysis conducted by the authors there was also a parallel process of control geodetic network review conducted at the request of GUGIK [URL 14]. The results of this review are now accessible at [GEOPORTAL 2, Mapy, 2020]. But despite the lack of access to the sample point 17330012 presented in figure 11 its "Stabilization status" is still presented as "good". Such information may lead to problems for potential users.

Despite the fact that the analysis covered Towns, which are equally intensively developing, significant differences can be noticed between them in the maintenance of the control points. In Myślenice, 57.1\% of the points were found, which was the majority of accessible points in this area. However, in Skawina the statistics revealed the opposite situation, namely $55.6 \%$ of the points were non-existent. This probably resulted from the unfavourable location of the control points in the area, which made them inaccessible. The last group is Rural Areas point location zone, where most of the points are located on singlefamily houses. The effect is that there is the greatest number of inaccessible points compared to other types of areas. The analysis demonstrated that only $33.3 \%$ of the points found could be used for surveys.

The next stage of the analysis concerned only those points that were found in the field. The diagram presented in Figure 7 illustrates the analysis of the remaining features of the points concerning:

- their fitness to perform surveys,

- their damage,

- consistency of their location with the presentation in the graphic part of topographic descriptions,

- consistency of their location with the location indicated by the B, L coordinates.

Considering the condition of the points found for the entire test database consisting of 153 points, it could be noticed that the location of all of them was consistent with the graphic part of topographic descriptions (Fig. 12). It was found that the surveys were not possible at 11 points, 10 of which were built-up as a result of renovation works performed, and 1 was destroyed. Such a small number of destroyed points is due to the fact that they are made of durable material and, as far as possible, protected by the owners of private facilities. 
The conclusion of the conducted analysis of the database of points of the basic second-order vertical control network is that majority of points that are in good condition are located in the City Centre zone. Nearly $50 \%$ of the control points that exist in the ZGiK database were not found in the Rural Areas and in the Towns zones. Out of 85 of all found points, 10 were built-up and one was destroyed, i.e. it was not possible to perform surveys on these points. Most commonly, it is building owners' fault, who unknowingly built up benchmarks, preventing their proper use.

When analysing the reference database, it should be noted that a large part of the points, as much as $36 \%$, have imprecise $B$ and $L$ coordinates, which causes discrepancy between the position of the points displayed in Google Earth (source: ZGiK coordinates, 2019) and the actual status in the field. The possible reasons for the existence of incorrect point coordinates were described in [Banasik, Ligas, Kudrys, Skorupa, Bujakowski 2012]. This fact is summarised in the bar charts below (Fig. 14), which indicate a necessity to propose a tool to improve the current state.

The greatest number of identified discrepancies occurs for the CC point location zone. It may be due to dense development and high buildings, hindering the accuracy of the surveys (Fig. 15).

For the $\mathrm{CCO}$ and T zones, i.e. less built-up areas, the location of most of the points corresponds to the data contained in Google Earth. However, for the CC and RA zones, this discrepancy exceeds 50\% (Fig. 15). The factors identified in the presented analysis, resulting in the inability to use control points correctly, confirm the necessity to introduce tools that enable their updating on an ongoing basis. The status of the test point database demonstrates the constant dynamics of changes that are not recorded in real time. Therefore, the regular transfer of information about the occurring changes by direct users of the control network seems to be the best form of maintaining a high quality database. Thus, the solution would be a mobile application on a mobile device, such as a mobile phone, accessible directly in the field. An exemplary data update using the developed Metrica application is presented in the figure 16.

\subsection{Examples of identified irregularities in the control network}

This part of the research paper presents selected examples relating to the determined criteria of the control network analysis. For specific situations 1-9 that were encountered, the appropriate A-G procedures may be applied to update data using the mobile application. The aim of the A-G procedures is to collect consistent information about the control network and then its correct transfer among surveyors, which will result in the update of the control network on an ongoing basis, together with the presentation of the current status in real time. The selected examples relate to the most common criteria in the analysed control network database, where data update is required.

\section{No access to visual inspection of the point - criterion 2}

The analysis of the point database was possible under the basic conditions: the point was accessible for inspection criterion 2, and the point existed in the field - criterion 3. The given example demonstrates a point located on an unused building, in a fenced area (Fig. 17). Verification of information about the point and the possibility of its surveying are hindered, because entering the area in the absence of the owner is not allowed.

Providing comments on hard-to-reach points makes it possible to plan surveys in the field more precisely, which greatly affects the economy of work - procedure A in the diagram (Fig. 7).

\section{Comparison of the point location: provided by ZGiK with the actual status in the field - criterion 6}

When verifying the information on the vertical control points, the source material included the topographic descriptions of points - criterion 4, as well as the B, L coordinates retrieved from ZGiK - criterion 6 (Fig. 18). These coordinates are necessary to determine the location of points in the field. The Google Earth application was used to present the location of the points. The function which can be used by a surveyor in the control network analysis, is based on the location of geodetic points. They are added by importing data from a file or by manually entering the coordinates. 
When comparing the position of the points displayed in Google Earth with the actual status in the field, significant discrepancies in the location of 31 points out of 153 were noticed. The figures in Table 5 illustrate several situations of location discrepancies. It is important to note that this issue occurs in each of the selected point location zones. The presentation of the actual location of the point is marked in red, while its incorrect indication based on the $B, L$ coordinates retrieved from ZGiK is marked in yellow. The encountered discrepancies reach up to $100 \mathrm{~m}$.

This type of error is very severe. There are many points of the vertical control network that present the actual location of the point for which there are no topographic descriptions. Only the address is given, which may frequently be insufficient to correctly determine the position of the benchmark. Therefore, it is especially important to enter the location coordinates correctly. The solution for the situation presented in the example for criterion 6 (Table 6) are surveys of navigation coordinates using a mobile phone and entering the measurement result into the mobile application - procedure $F$ from the diagram (Fig. 7). This activity will help other people using the point to locate it correctly.

Table 6.Comparison of point coordinates retrieved from ZGiK with surveys using mobile device. Source: Authors' original contribution

\begin{tabular}{|llll|}
\hline Point number & Coordinate source & B & L \\
\hline 16330023 & ZGiK & $50^{\circ} 05^{\prime} 22,7^{\prime \prime}$ & $19^{\circ} 57^{\prime} 28,4^{\prime \prime}$ \\
\cline { 2 - 4 } & Survey of navigational coordinates & $50^{\circ} 05^{\prime} 21^{\prime \prime}$ & $19^{\circ} 57^{\prime} 28^{\prime \prime}$ \\
\cline { 2 - 4 } & $\Delta$ & $1.7^{\prime \prime}$ & $0.4^{\prime \prime}$ \\
\hline
\end{tabular}

The captured values of the $B, L$ coordinates after the survey should be entered using the mobile application for updating the information of geodetic network points as appropriate for the correct location of the control point.

\section{Possibility to perform surveys on a point against information that the survey marker is destroyed - criterion 7}

By analysing the control network in accordance with criterion 7, it was found that 4 points had incorrect information on the topographic description, informing about their destruction (Fig. 19). The condition of the points was verified in the field and an exemplary topographic description is presented in the photo (Fig. 19). The survey marker is in good condition, it is still possible to measure it, it is located in the place indicated by the graphic part of the topographic description.

In such a situation as presented in the example for criterion 7, erroneous information must be updated. It should be done by adding a photo of the point and a new topographic description, measuring new $B, L$ coordinates and providing information about the possibility of performing surveys on the point - procedure $D$ in the diagram (Fig. 7).

\section{Built-up point - criterion 8}

Nowadays, we often deal with survey markers in theoretically very good technical condition which, after being built-up with insulation, become useless for levelling surveys. The reason lies in the ignorance of the owners who, wanting to protect them, are not aware of how surveyors use these points during surveys (Fig. 20). Similar situations were encountered 10 times during the control network analysis.

In the cases presented in the example for criterion 8, a surveyor using the application should post a photo and assign the point status as "not fit for surveys". He or she may also provide information about the inability to perform surveys on the point, stating a specific reason for such a situation in the comments. In the application, the proposed scheme of conduct is point $\mathrm{E}$ from the scheme (Fig. 7).

\section{Lack of information about point destruction - criterion 9}


Few destroyed points were identified during the field verification which still function as useful for surveys. In the example illustrated in the photograph (Fig. 21), it can be seen that the survey marker has been destroyed. It is therefore not possible to perform a survey on this point.

In the case presented for criterion 9, the surveyor using the application should post a photo showing the actual point, give it the status of the point "not fit for surveys/destroyed" and include this information in the topographic description. In the comments to the point, it is possible to provide detailed information on the current situation. In the application, the proposed scheme of conduct is point $\mathrm{E}$ from the scheme (Fig. 7).

\section{Conclusions}

Maintaining up-to-date information about the points of the basic vertical control network is a difficult task due to the extensive range of locations of these points and the lack of control over some changes taking place e.g. on private properties. Therefore, in the designed Metrica application, it was decided to solve this problem by allowing surveyors to introduce changes to the information about the point.

The database used to design the application was verified by authors during a field inspection. From the analysis of the collected data, conclusions were drawn about the condition of the vertical control points in the selected area. Only $55.6 \%$ of the points were identified in the field, most of them were found in the City Centre point location zone. This was due to their location in generally accessible places as well as the fact that these points were used more frequently and needed to be kept in good condition. When analysing the database, it was noticed that some data were updated over the year in the Geoportal application, but these were individual cases, in spite of the 2019 review at the request of GUGiK. Control network surveys were carried out, thanks to which the location of incorrectly indicated points is now correctly presented on the map. However, this update process does not take place in real time, hence the need to use a tool for the update of the control network on an ongoing basis. The information contained in the topographic descriptions, which sometimes incorrectly suggested that the point was destroyed, was also taken into account.

The final result of the work is the preparation of the Metrica mobile application, which has been implemented in order to update the control network.

The application has been developed with the use of a test database of points, according to an original authors' concept. It is now possible to extend the application with new attributes and validation rules and conduct updates for various types of geodetic network.

Due to the extensive character of the discussed subject, the study has been divided into two parts. The continuation of this study is the second research paper, which presents the development of a mobile application for the update of the geodetic control network. It will present in detail the procedures and IT application development processes.

\section{Abbreviations}

- ZGiK- Geodetic and Cartographic Documentation Resource,

- ODGiK - Geodetic and Cartographic Documentation Centre,

- PODGiK - District Geodetic and Cartographic Documentation Centre,

- CC - City Centre

- CCO - City Centre Outskirts,

- T - Town,

- RA - Rural Area.

\section{Declarations}

Page 14/29 


\section{Author contribution statement}

Anna Przewięźlikowska: Conceptualization, Data acquisition, Methodology, Research, Writing - review \& editing, Visualization, Supervision, Formal analysis

Klaudia Wójcik \& Wioletta Ślusarczyk: Methodology, Research, Writing - original draft \& editing, Visualization, Mobile application development

\section{Data availability statement:}

Data from the Polish vertical control network are currently available from the repository of the Polish Geoportal: http://www.gugik.gov.pl/pzgik/zamow-dane/osnowy-geodezyjne,-grawimetryczne-i-magnetyczne

Other datasets generated during and/or analysed during the current study are available from the corresponding author on reasonable request.

\section{References}

1. Banasik, P., Ligas, M., Kudrys, J., Skorupa, B. \& Bujakowski, K. (2012). Transformacja wysokości z układu Kronsztadt'60 do układu Kronsztadt'86 na przykładzie powiatu krakowskiego - Transformation of elevations from Kronsztadt'60 System to Kronsztadt'86 System using the example of the Kraków District, Przegląd Geodezyjny, 2012 r., 84 nr 4, s. 6-13; ISSN 00332127, tekst: http://www.sigma-not.pl/download.do? mode=sps\&id=66926

2. Bielecka, E., Pokonieczny, K. \& Kamiński, P. (2014). Study on spatial distribution of horizontal geodetic control points in rural areas. Acta Geod Geophys 49, 357-368 (2014). https://doi.org/10.1007/s40328-014-0056-6

3. Brovelli, M., Minghini, M. \& Zamboni, G. (2016). Public participation in GIS via mobile applications, ISPRS Journal of Photogrammetry and Remote Sensing, Volume 114, April 2016, Pages 306-315, https://doi.org/10.1016/j.isprsjprs.2015.04.002

4. Borowski, Å., Lal, A. \& Nepelski, K. (2017). Analiza osiadania wybranych typów znaków osnowy geodezyjnej. https://www.researchgate.net/publication/328407796_Analiza_osiadania_wybranych_typow_znakow_osnowy_geodezyjnej

5. Ell, P. et al. i inni(2018). MobiQ: A modular Android application for collecting social interaction, repeated survey, GPS and photographic data. SoftwareX, Volume 7, January-June 2018, Pages 143-149, https://doi.org/10.1016/j.softx.2018.04.006

6. Gazcón, N., Nagel, T., Bjerg, J. \& Castro, E. S(2018). Fieldwork in Geosciences assisted by ARGeo: A mobile Augmented Reality system, Computers \& Geosciences, Volume 121, December 2018, Pages 30-38, https://doi.org/10.1016/j.cageo.2018.09.004

7. GEOPORTAL 2 Maps. (2020). Retrieved August 25, 2020 from GEOPORTAL 2 location: https://mapy.geoportal.gov.pl/imap/Imgp_2.html

8. GEOPORTAL - Mobile applications. (2020). Retrieved August 25, 2020 from GEOPORTAL 2 location: https://www.geoportal.gov.pl/aplikacje/mobilne

9. GEOPORTAL - basic control networks. (2020). Retrieved August 18, 2020 from GEOPORTAL location: https://www.geoportal.gov.pl/dane/osnowy-podstawowe

10. Google Earth. (2020). Retrieved August 17, 2020 from https://www.google.com/earth/

11. Graszka, W., Pielasa, E., Piętka, D. \& Wajda, S. (2016). Podstawowa osnowa wysokościowa, grawimetryczna i magnetyczna ocena stanu i prognozy rozwoju. Seminarium Współczesne problemy podstawowych osnów geodezyjnych w Polsce, (str. 39). Grybów. Pobrano z lokalizacji https://docplayer.pl/28302758-Podstawowa-osnowa-wysokosciowa-grawimetryczna-imagnetyczna-ocena-stanu-i-prognozy-rozwoju.html

12. Hanus, P., Pęska-Siwik, A., Benduch, P. \& Szewczyk, R. (2020). Comprehensive assessment of the quality of spatial data in records of parcel boundaries, Measurement, Volume 158, 1 July 2020, 107665, https://doi.org/10.1016/j.measurement.2020.107665

Page $15 / 29$ 
13. Krawiec, J. (2017). Bezpieczne programowanie w Javie - kontrola dostępu. @Wydawnictwo UR 2017, http://repozytorium.ur.edu.pl/handle/item/3102

14. Krzyżek, R. \& Przewięźlikowska, A. (2017). Accuracy assessment in determining the location of corners of building structures using a combination of various measurement methods, Reports on Geodesy and Geoinformatics, ISSN 23918152. - 2017 vol. 104, s. 48-56. - Tryb dostępu: https://goo.gl/c3QNju [2018-01-22]. - Bibliogr. s. 56, Abstr., https://doi.org/10.1515/rgg-2017-0014

15. Krzyżek, R., Uchański, J. \& Piotr Falkowski, P. (2017). The SWSC Compilation Algorithm enhancing the reliability and accuracy of determining rectangular coordinates of corners of building structures with photogrammetric method, Measurement, Volume 110, November 2017, Pages154-165, https://doi.org/10.1016/j.measurement.2017.06.016

16. Maciuk, K., Pęska - Siwik, A., El-Mowafy, A., Borowski, L. \& Apollo, M. (2021). Crustal Deformation Across and beyond Central Europe and Its Impact on Land Boundaries, Resources. 10 (2021) 15, https://doi.org/10.3390/resources10020015.

17. Medved, K., Kuhar, M. \& Koler, B. (2018). Regional gravimetric survey of central Slovenia, Measurement, Volume 136, March 2019, Pages395-404, https://doi.org/10.1016/j.measurement.2018.12.065

18. Mrówczyńska, M., Sztubecki, J. \& Greinert, A. Compression of results of geodetic displacement measurements using the PCA method and neural networks, Measurement, Volume 158, 1 July 2020, 107693, https://doi.org/10.1016/j.measurement.2020.107693

19. Przewięźlikowska, A. (2020). Legal aspects of synchronising data on real property location in polish cadastre and land and mortgage register, Land Use Policy, Volume 95, June 2020, 104606, https://doi.org/10.1016/j.landusepol.2020.104606

20. Regulation 2011 - Regulation of the Minister of Internal Affairs and Administration on technical standards for the performance of topographic surveys as well as the elaboration and transfer of the results of these surveys to the National Geodetic and Cartographic Documentation Centre (Journal of Laws 2011, item 1572).

21. Regulation 2012 - Regulation of the Minister of Administration and Digitization of 14 February 2012 on geodetic, gravimetric and magnetic control networks (Journal of Laws of 2012, item 352)

22. Regulation 2020 - Regulation of the Minister of Development of 18 August 2020 on technical standards for the performance of topographic surveys as well as the elaboration and transfer of the results of these surveys to the National Geodetic and Cartographic Documentation Centre (Journal of Laws of 2020, item 1429)

23. Schildt, H. Java przewodnik dla początkujących. Wydanie VI (Wydawnictwo HELION, Polska, 2015).

24. Geodetic and Cartographic Law 1989 - the Act of 17 May 1989 Geodetic and Cartographic Law (Journal of Laws of 2020, items $276,284,782,1086)$.

25. Wolski, B., Derezińska, A. \& Środowisko (2008). Badania niezawodności eksploatacyjnej osnowy wysokościowej stabilizowanej na obszarze gruntów ekspansywnych. Czasopismo Techniczne.

https://repozytorium.biblos.pk.edu.pl/resources/34344

26. URL 1: (2020). Retrieved September 9, 2020, from Geoportal location: https://mapy.geoportal.gov.pl/imap/Imgp_2.html

27. URL 2: BinSoft. (2011-2020). Retrieved August 8, 2020 from Asystent Geodety location: http://www.asystent-geodety.pl

28. URL 3: MERGDATA survey:https://play.google.com/store/apps/details?id=com.mergdata.surveys\&hl=en_US\&gl=US

29. URL 4: GIS Mobile Applications: https://www.igismap.com/5-best-gis-applications-for-android-and-ios/

30. URL 5: Locus GIS - offline geodata collecting, SHP edits: https://play.google.com/store/apps/details? id=menion. android.locus.gis\&hl=en_US\&gl=US

31. URL 6: Technical Guideline G-2. (1986). Retrieved August 2020, from location http://arch.gugik.gov.pl/_data/assets/pdf_file/0017/25127/1344_g-2_wysokosciowa_osnowa_geodezyjna.pdf

32. URL 7: Appendix to Technical Guideline G-2. (2001). Retrieved August 28, 2020 from location http://www.blueworld.pl/geodezja/inawodcje/G2_2001.pdf

33. URL 8: Development Strategy of the Town and Commune of Myślenice for years 2016-2020 (2016). Retrieved August 18, 2020 from location https://myslenice.pl/pro_myslenice/zasoby/files/strategia-2016-2020.pdf

34. URL 9: Skawina Commune (2009). Retrieved August 18, 2020 from location https://www.gminaskawina.pl/

Page $16 / 29$ 
35. URL 10: Poland in numbers - Czernichów Commune (2020). Retrieved August 18, 2020 from location https://www.polskawliczbach.pl/gmina_Czernichow_malopolskie

36. URL 11: Poland in numbers - Liszki Commune (2020). Retrieved August 18, 2020 from location https://www.polskawliczbach.pl/gmina_Liszki

37. URL 12: Poland in numbers - Świątniki Górne (2020). Retrieved August 18, 2020 from location https://www.polskawliczbach.pl/gmina_Swiatniki_Gorne

38. URL 13: Poland in numbers - Wieliczka (2020). Retrieved August 18, 2020 from location https://www.polskawliczbach.pl/gmina_Wieliczka

39. URL 14: http://www.gugik.gov.pl/bip/zamowienia-publiczne/2019-powyzej-kwoty-okreslonej-w-art.-4-pkt-8-pzp/przeglad,inwentaryzacja-i-konserwacja-podstawowej-osnowy-geodezyjnej-na-obszarze-kraju-obiekt-4735

\section{Tables}

Due to technical limitations, table 5 is only available as a download in the Supplemental Files section.

\section{Figures}

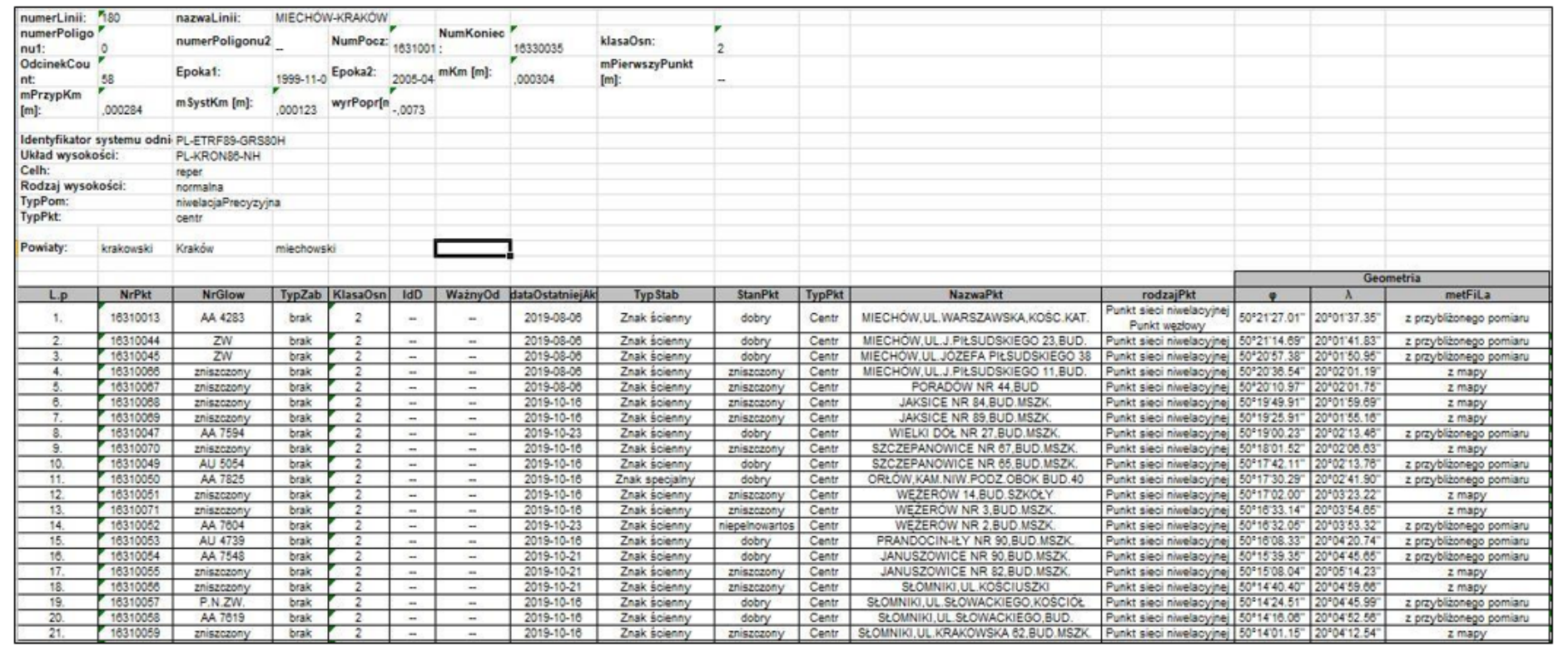

\section{Figure 1}

File with data on vertical control network retrieved from Geoportal. Source [URL 1] 


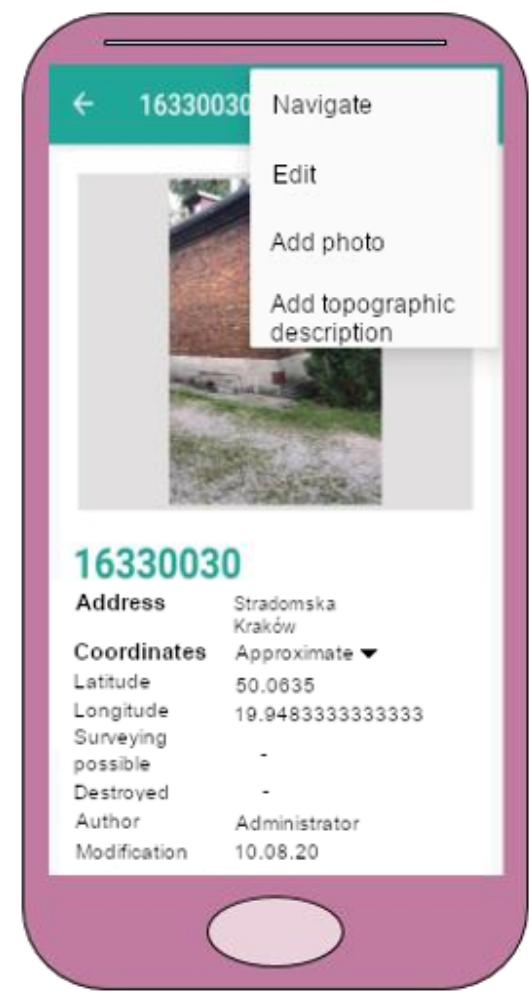

METRICA APP

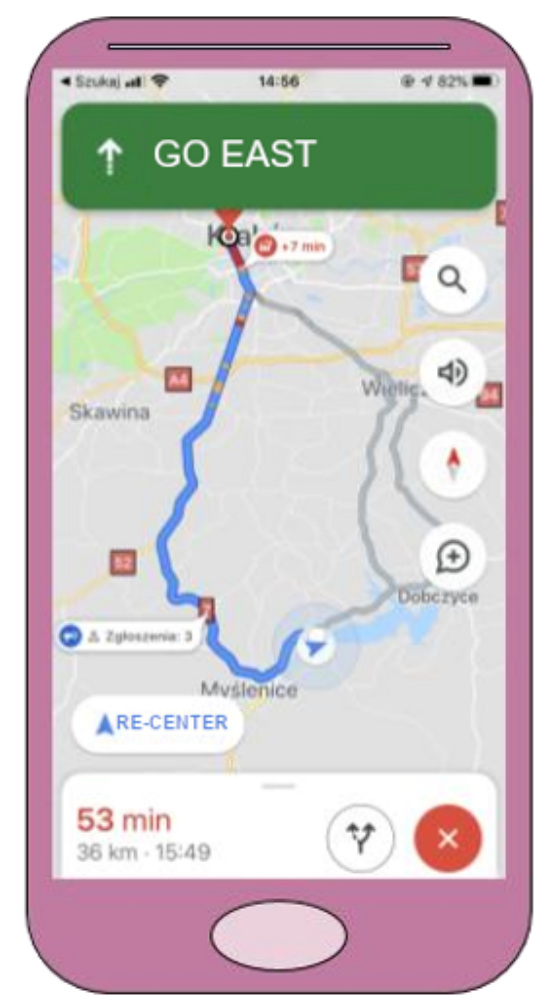

GOOGLE MAPS

\section{Figure 2}

Data presentation in the proprietary METRICA application. Source: Authors' original contribution

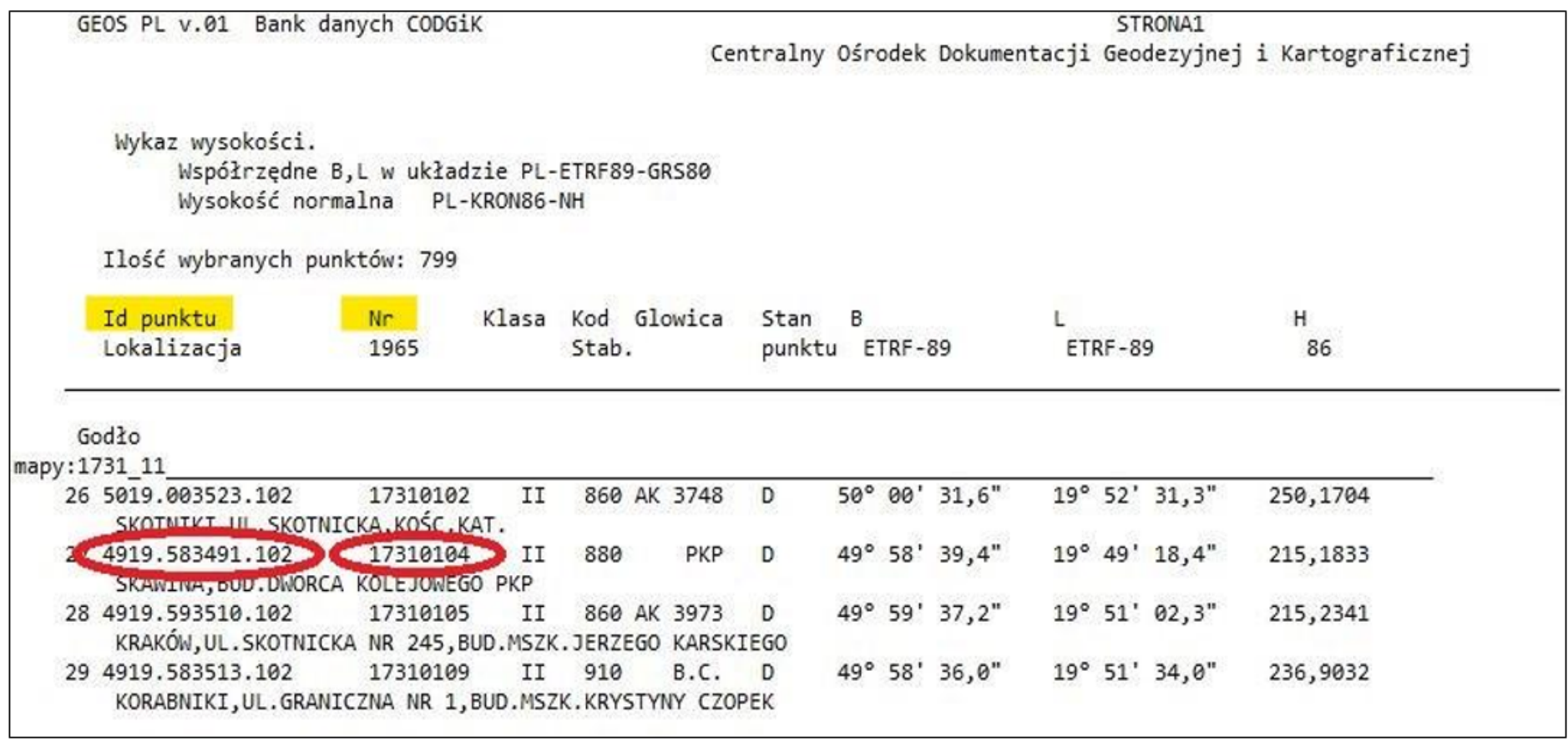

\section{Figure 3}

Fragment of data file retrieved from ZGiK. Source: ZGiK, 2019 


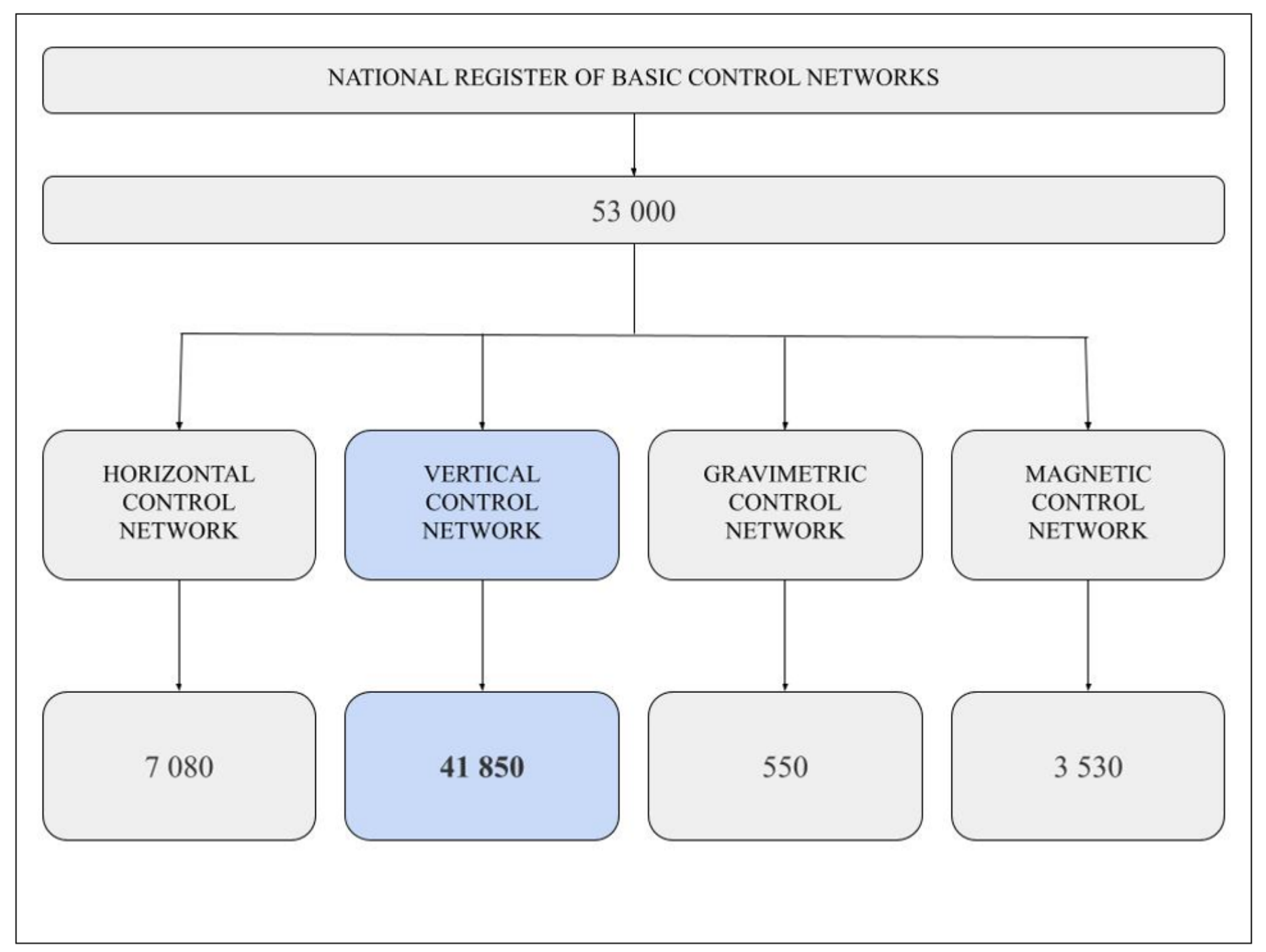

Figure 4

Number of points of geodetic network. Source [GEOPORTAL - basic control networks, 2020]

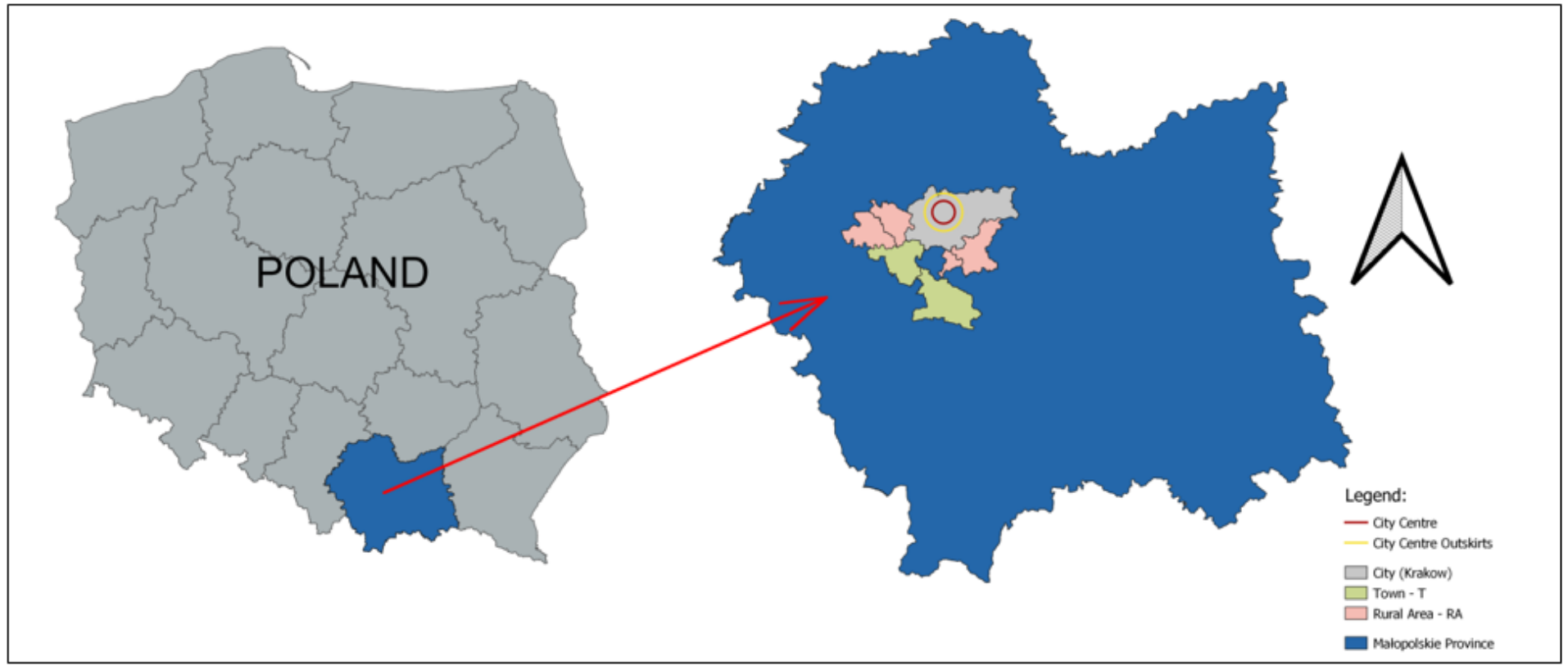




\section{Figure 5}

Selected locations in Małopolskie Province. Source: Authors' original contribution

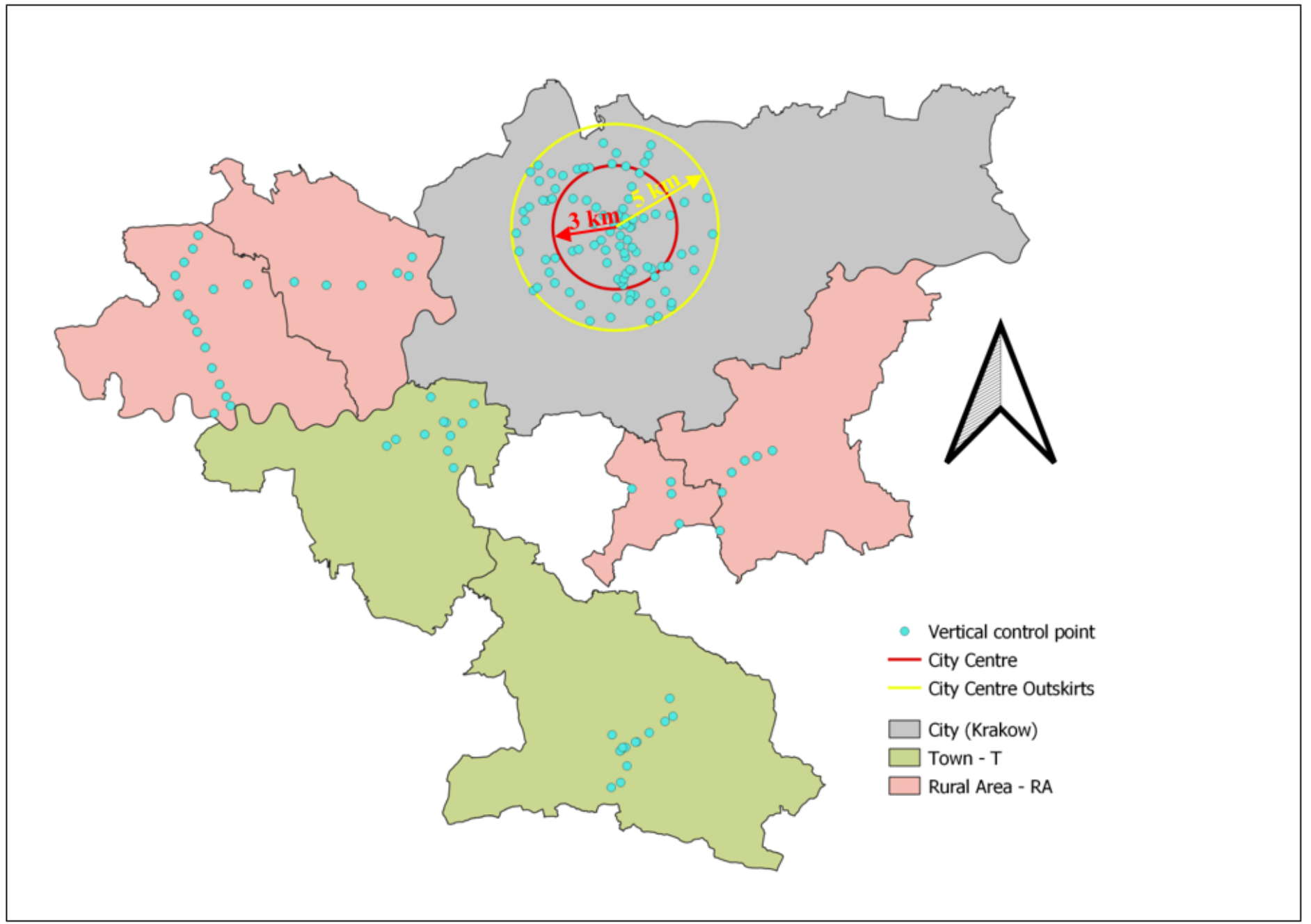

\section{Figure 6}

Presentation of selected control points in selected types of locations. Source: Authors' original contribution 


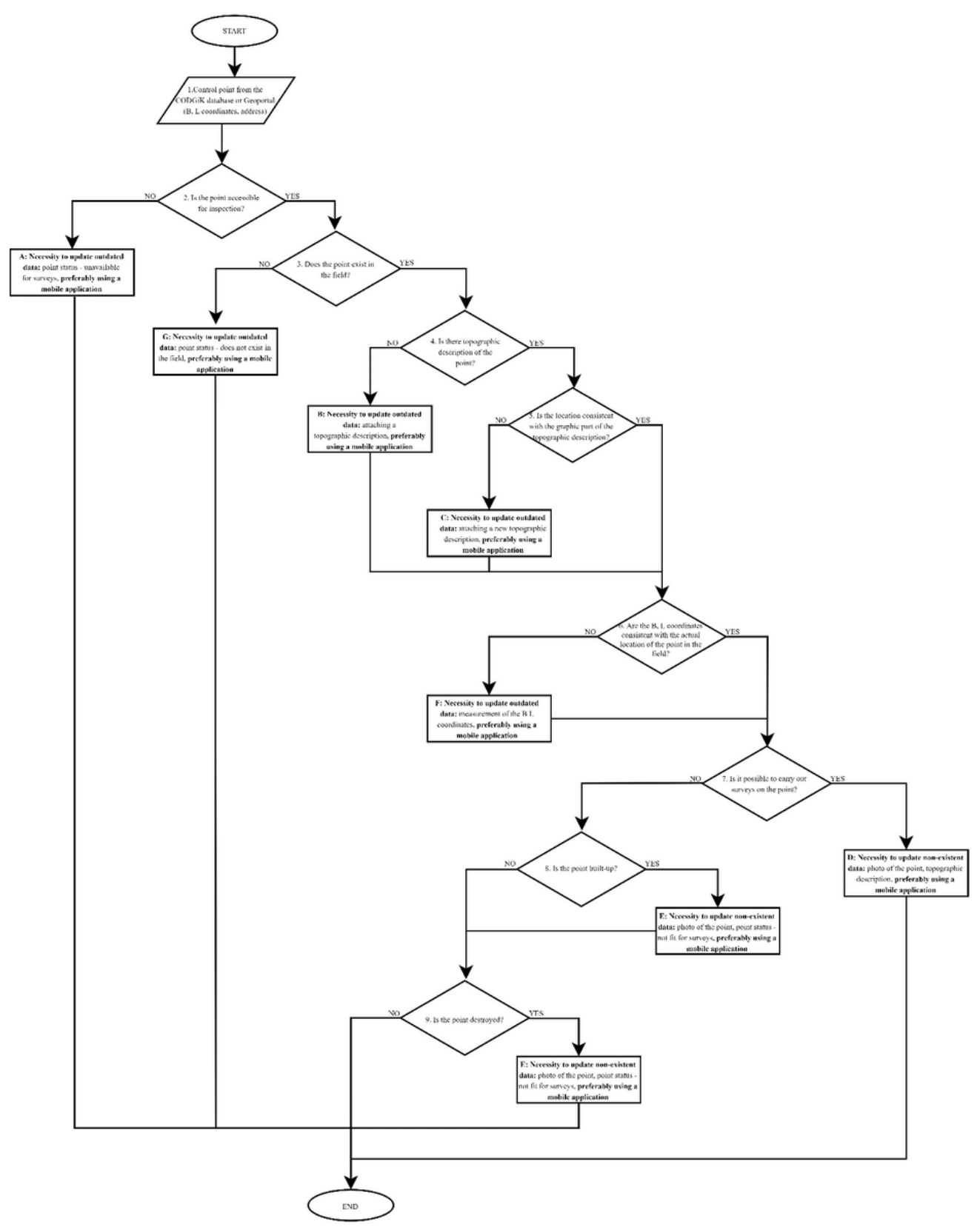

Figure 7

Diagram of control network analysis according to adopted criteria. Source: Authors' original contribution 


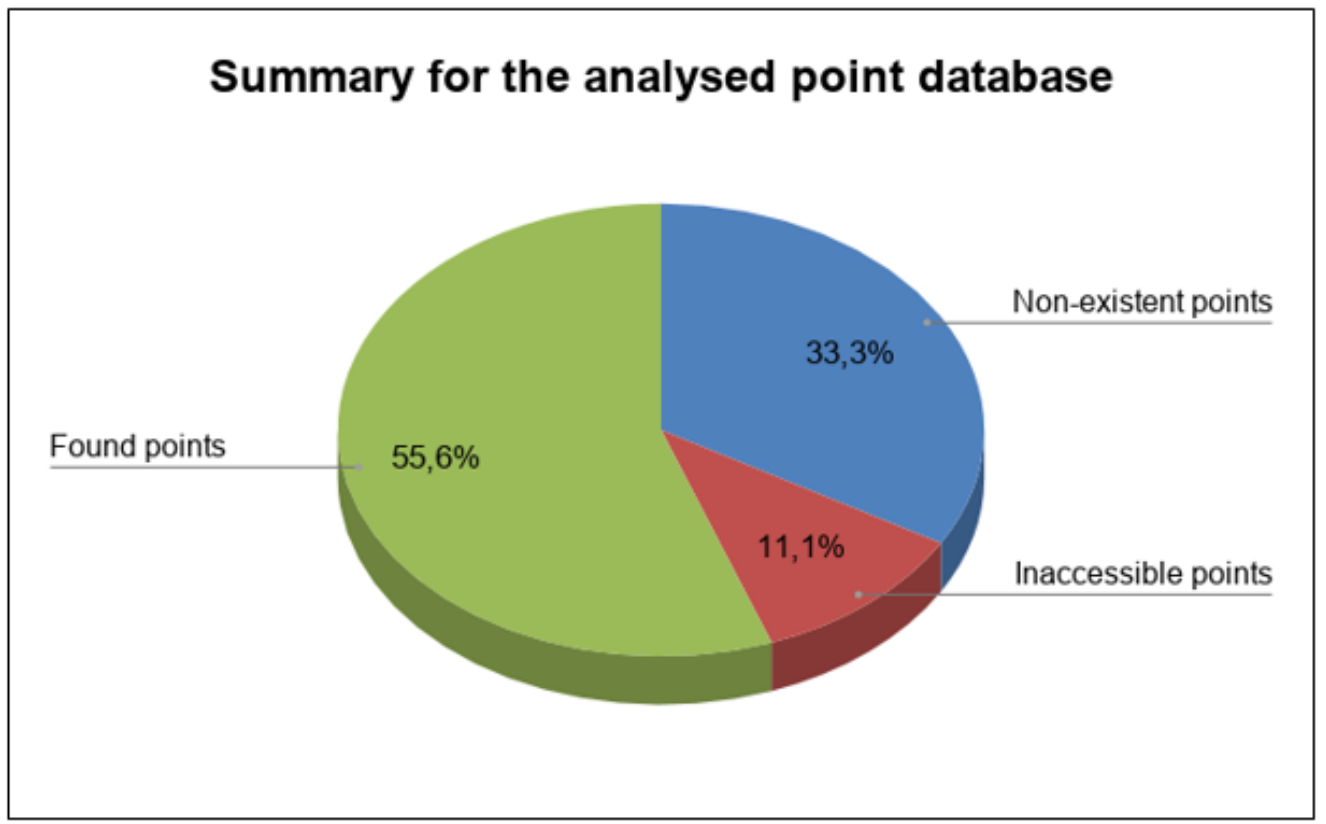

\section{Figure 8}

Summary of results obtained for analysed database. Source: Authors' original contribution
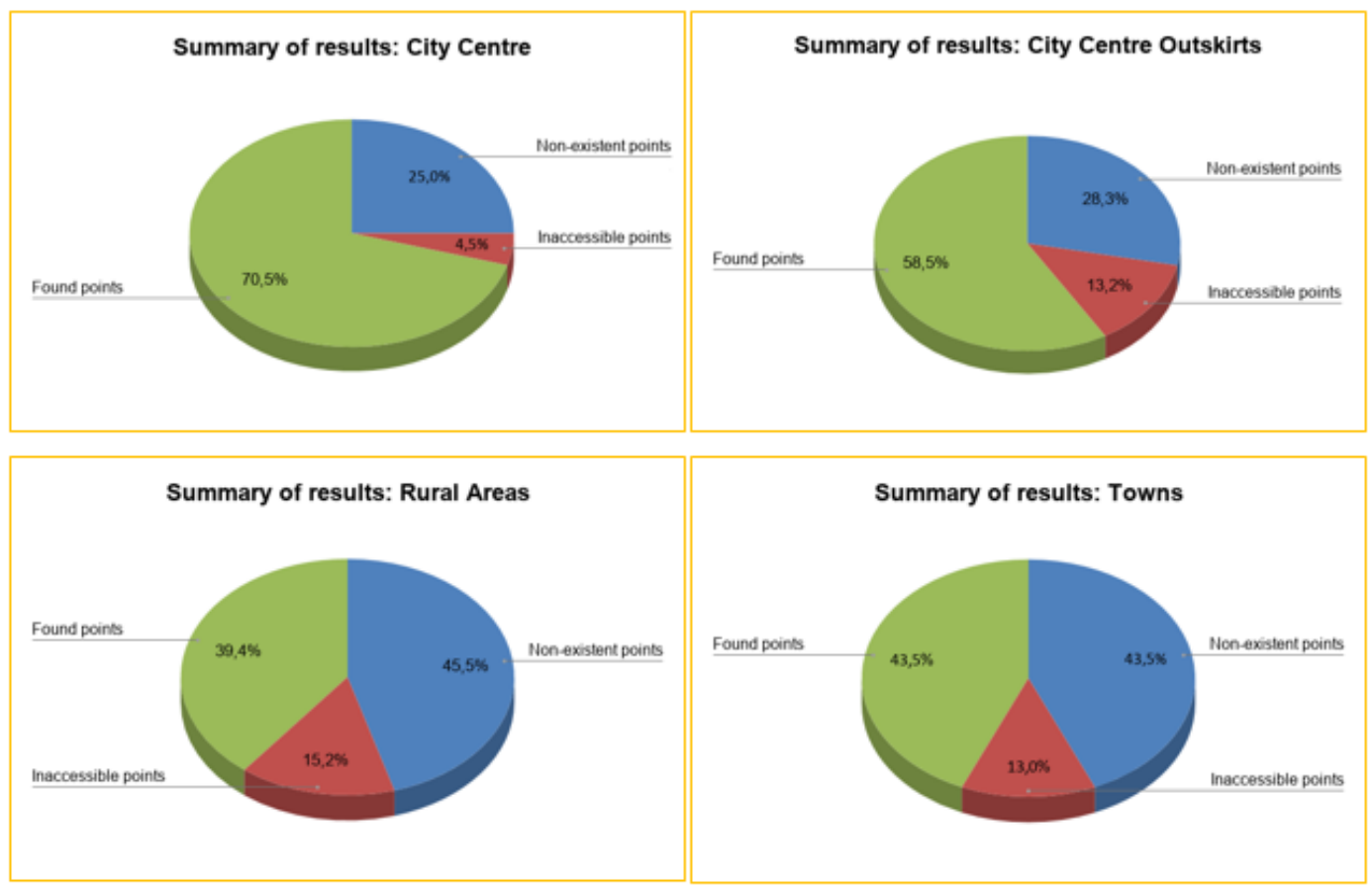

\section{Figure 9}

Comparative results of point occurrence in various areas. Source: Authors' original contribution 


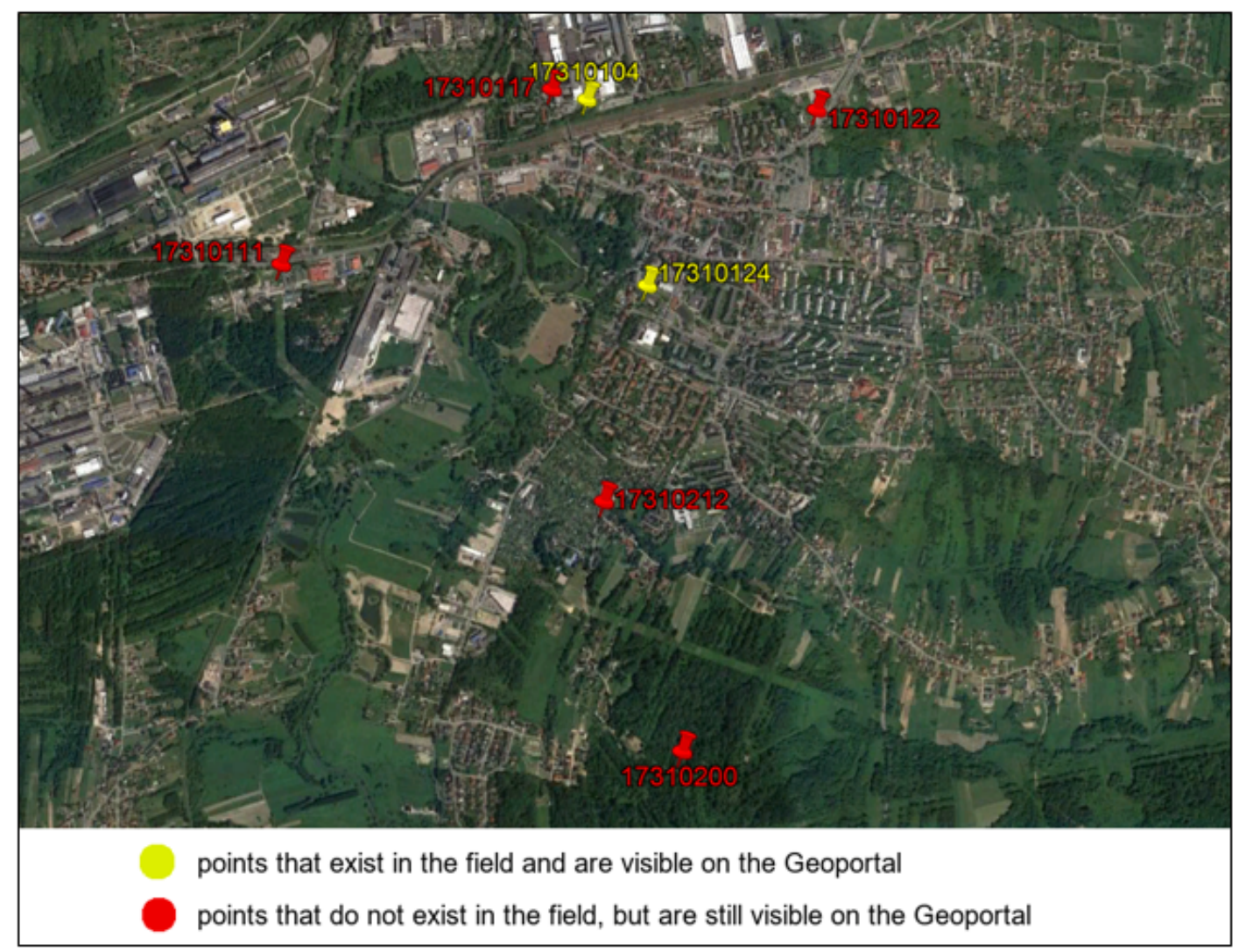

\section{Figure 10}

Presentation of points non-existent in the field but still existing in Geoportal in "good" status. Source: Authors' original contribution 


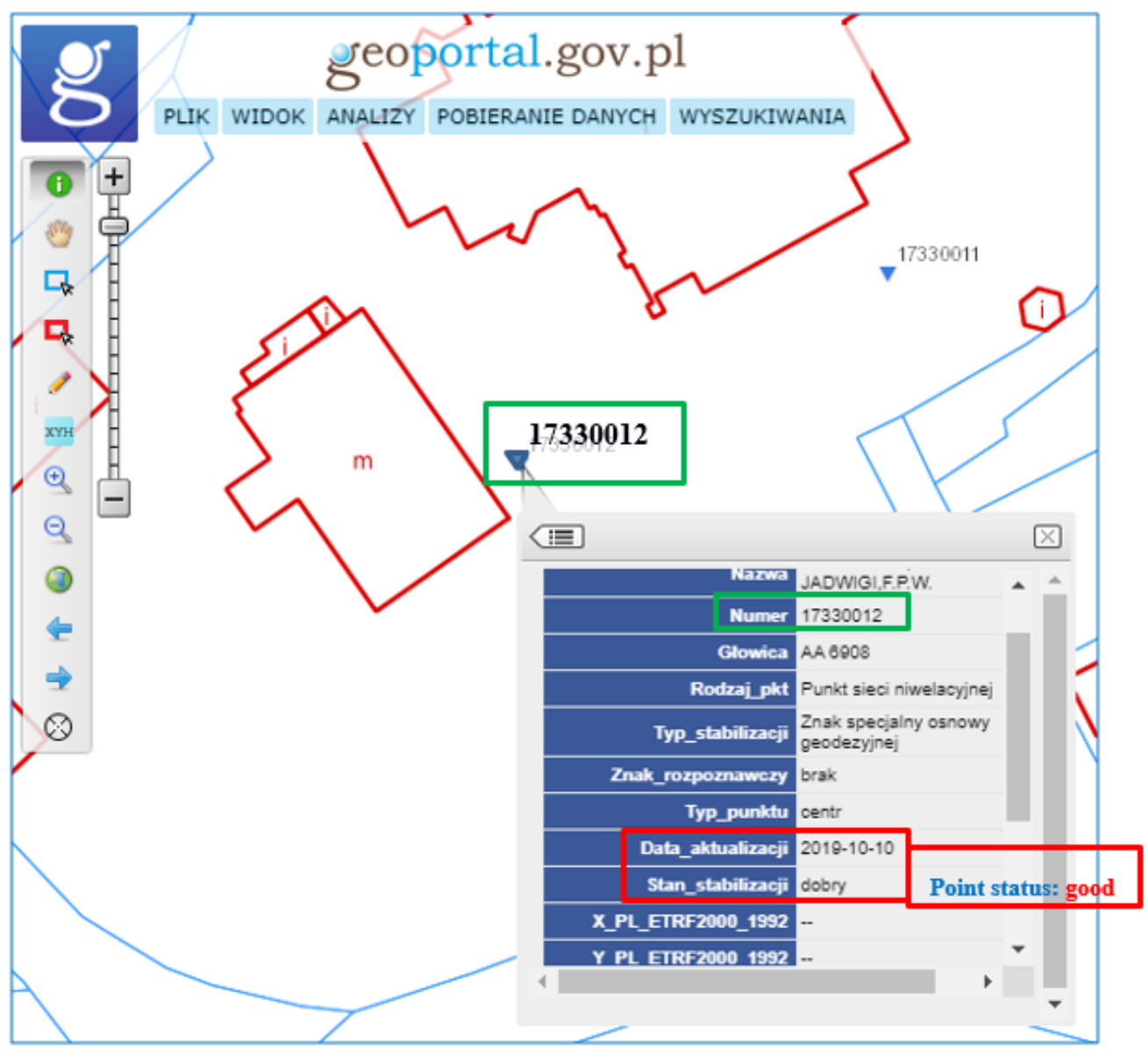

Figure 11

Method of displaying erroneous information in Geoportal about a point, that is not accessible for measurement. Status of stabilization - good. Source [GEOPORTAL 2 Maps, 2020]

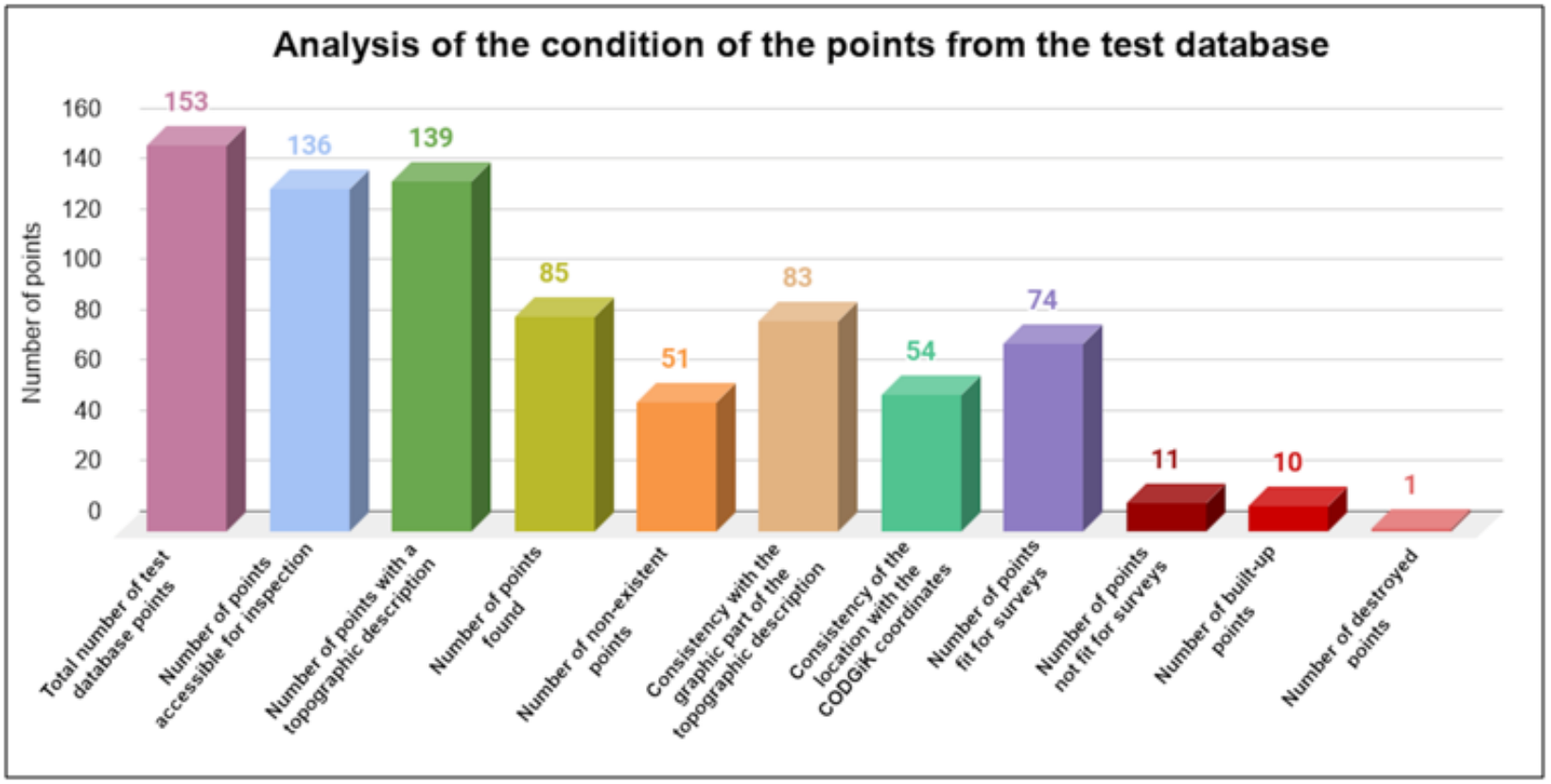

Figure 12

Analysis of condition of points for test database consisting of 153 points. Source: Authors' original contribution 

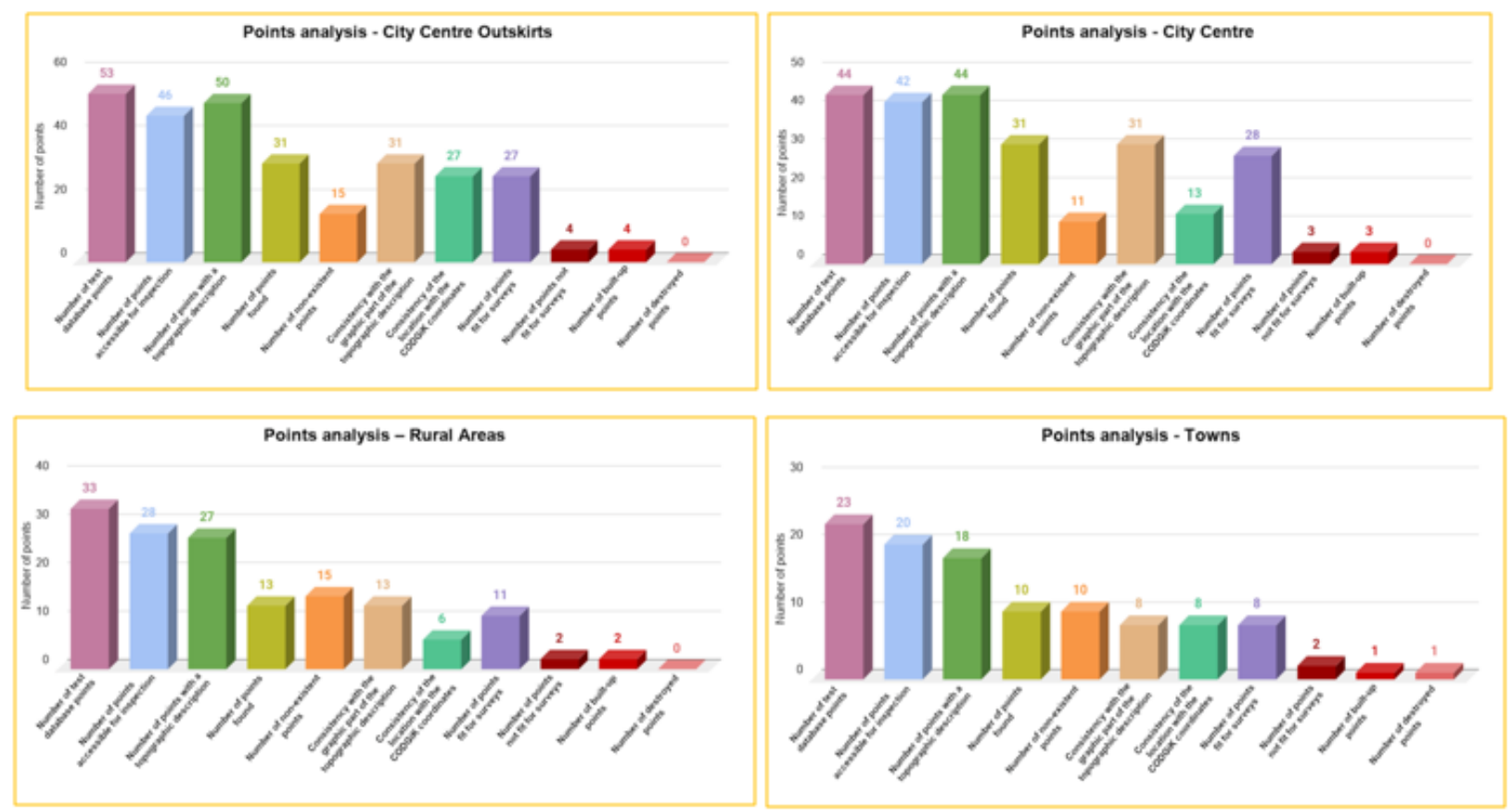

Figure 13

Analysis of condition of points in individual areas of City Centre zone. Source: Authors' original contribution

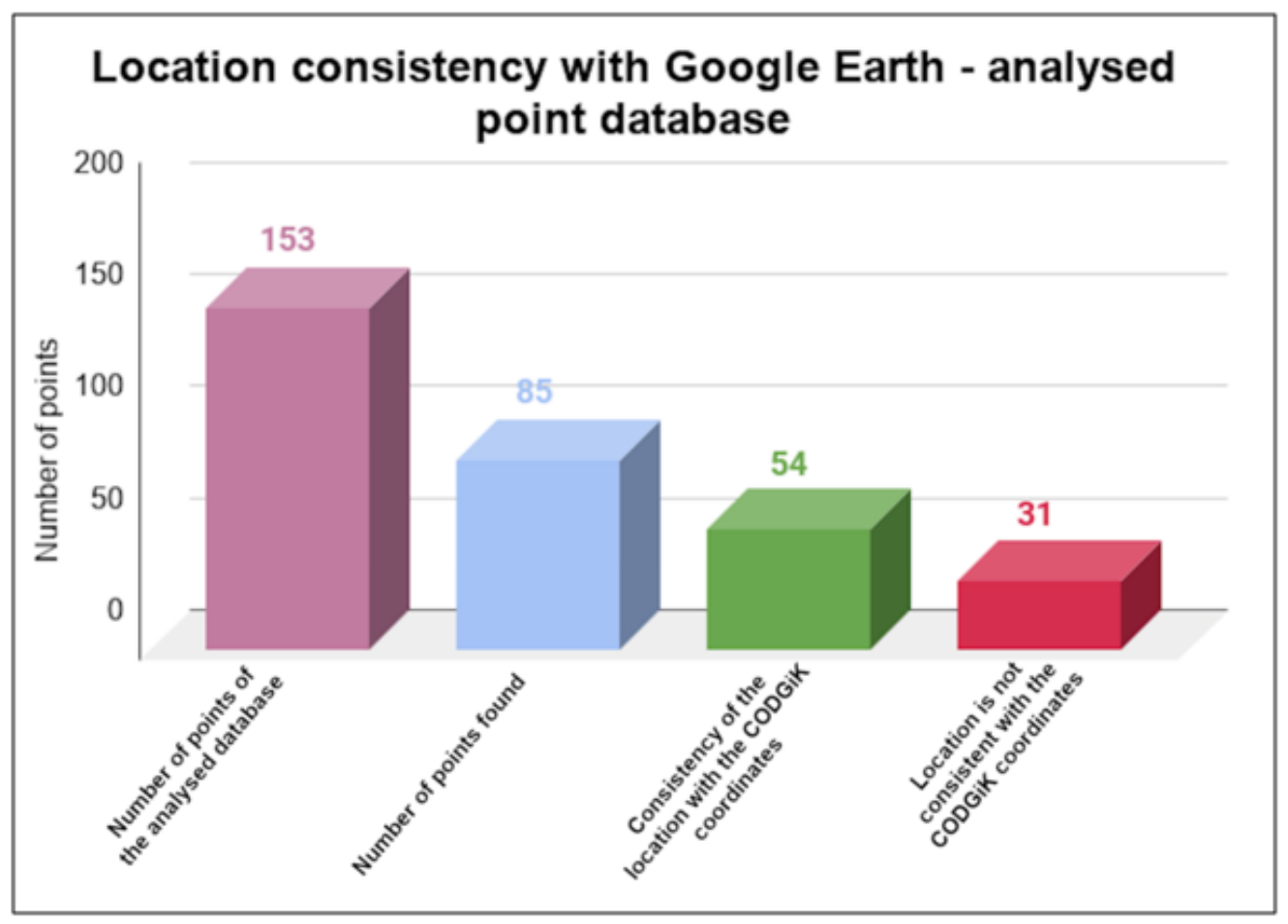

Figure 14

Location consistency for test database. Source: Authors' original contribution 


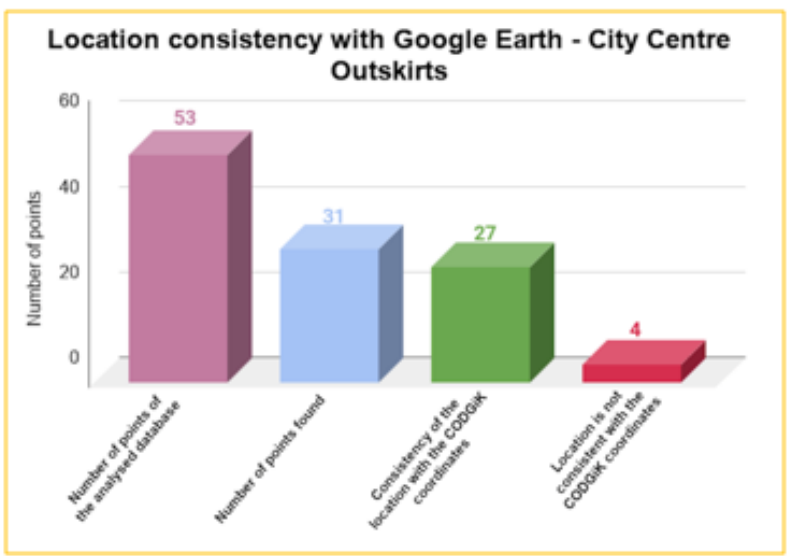

Location consistency with Google Earth - City Centre

Location consistency with Google Earth - Rural Areas
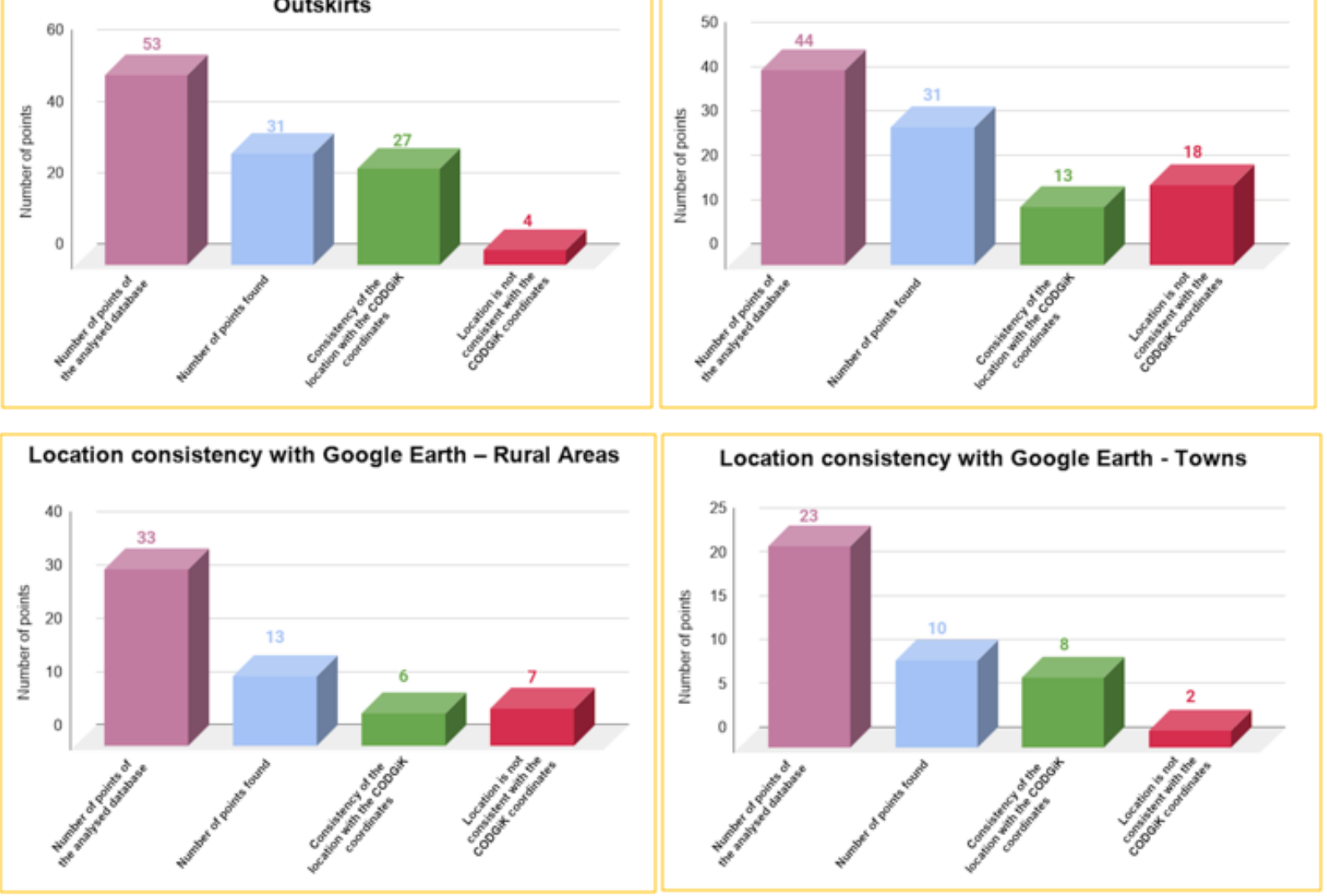

\section{Figure 15}

Consistency of point location in the field with presentation in Google Earth. Source: Authors' original contribution

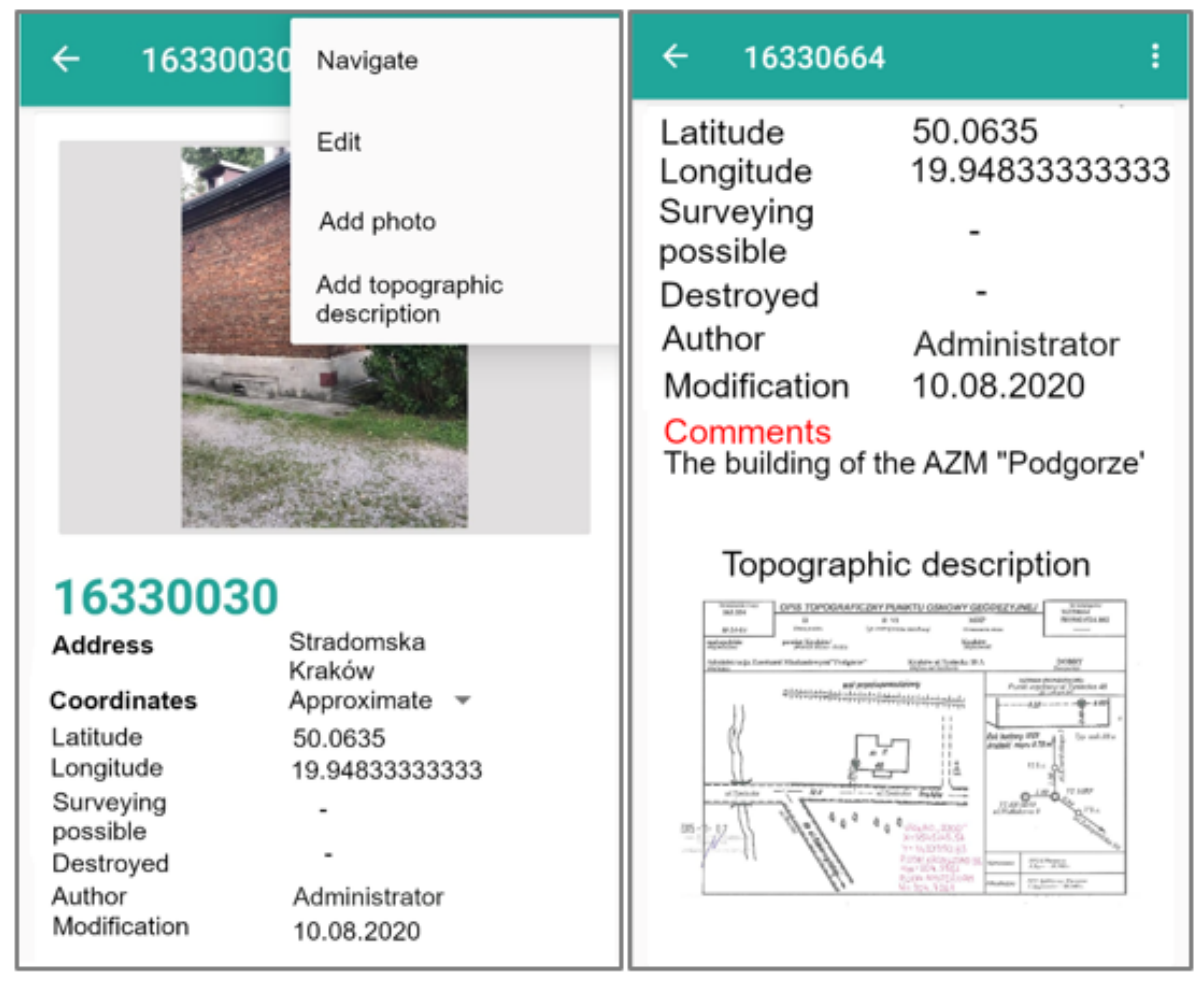

Figure 16 


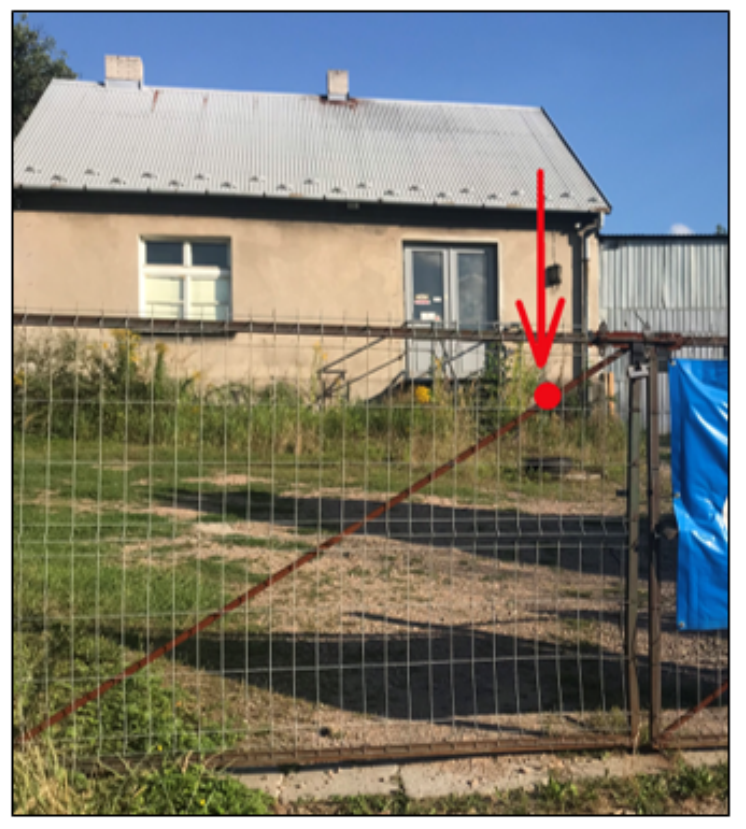

Figure 17

Photograph of building with inaccessible point. Source: Authors' original contribution

GEOS PL v.01 Bank danych CODGiK

Wykaz wysokości.

Współrzędne $B, L$ w układzie PL-ETRF89-GRS80

Wysokość normalna PL-KRON86-NH

Ilość wybranych punktów: 799

$\begin{array}{lllllll}\text { Id punktu } & \text { Nr } & \text { Klasa } & \text { Kod Glowica } & \text { Stan B } & \text { L } & \text { H } \\ \text { Lokalizacja } & 1965 & & \text { Stab. } & \text { punktu ETRF-89 } & \text { ETRF-89 } & 86\end{array}$

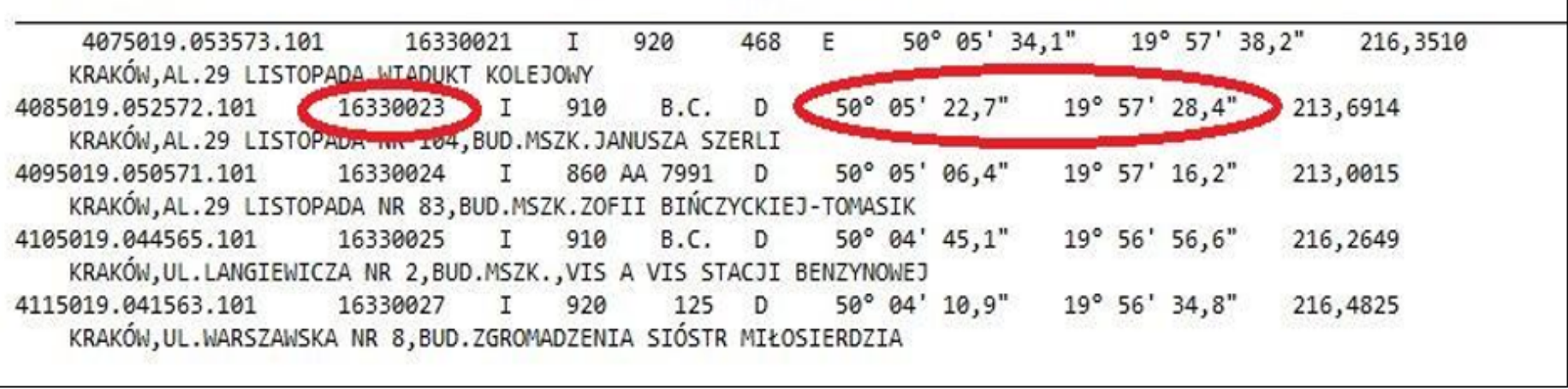

\section{Figure 18}

Presentation of data relating to B, L coordinates. Source: ZGiK, 2019 

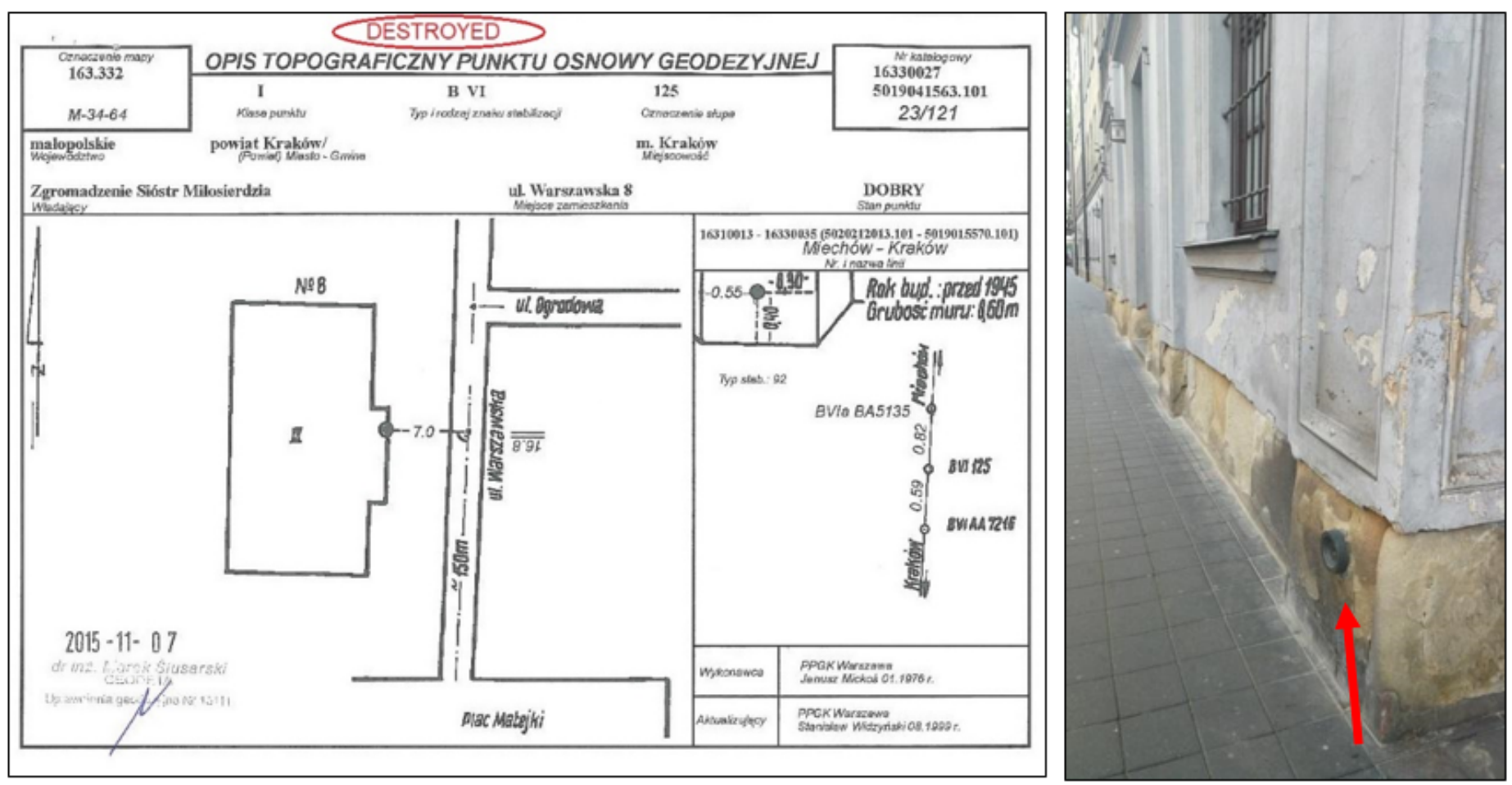

\section{Figure 19}

Topographic description and photo of theoretically destroyed point. Source: ZGiK, 2019
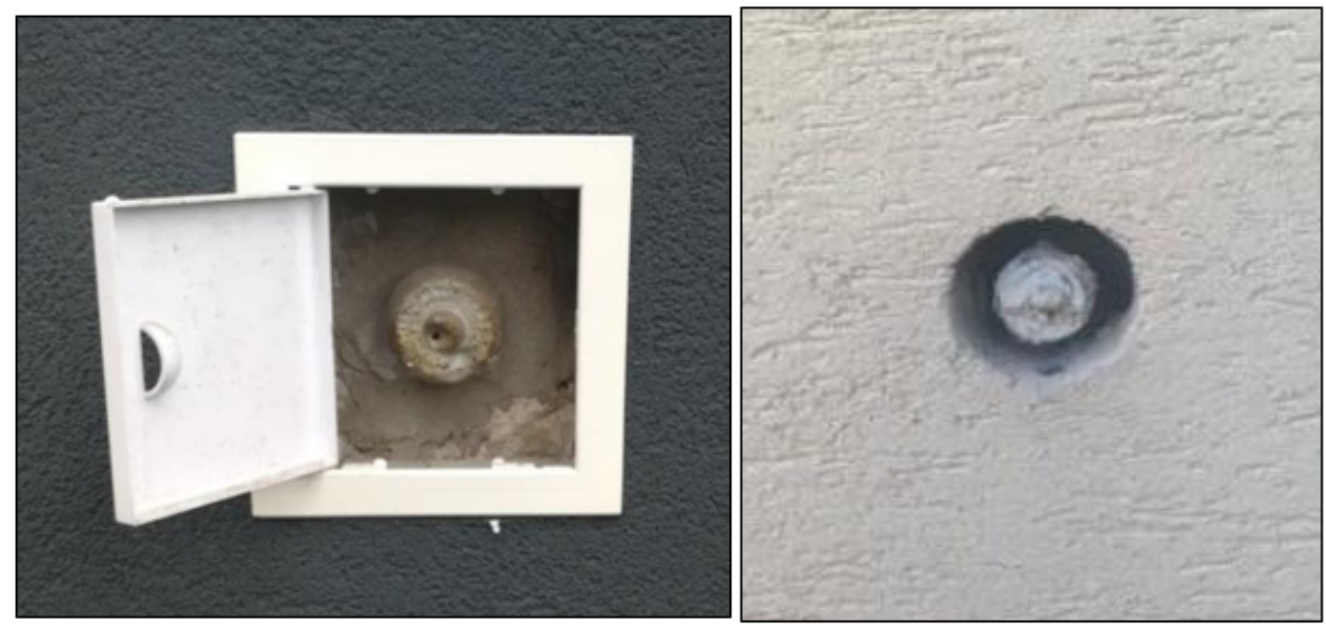

Figure 20

Points built-up in incorrect manner. Source: Authors' original contribution 

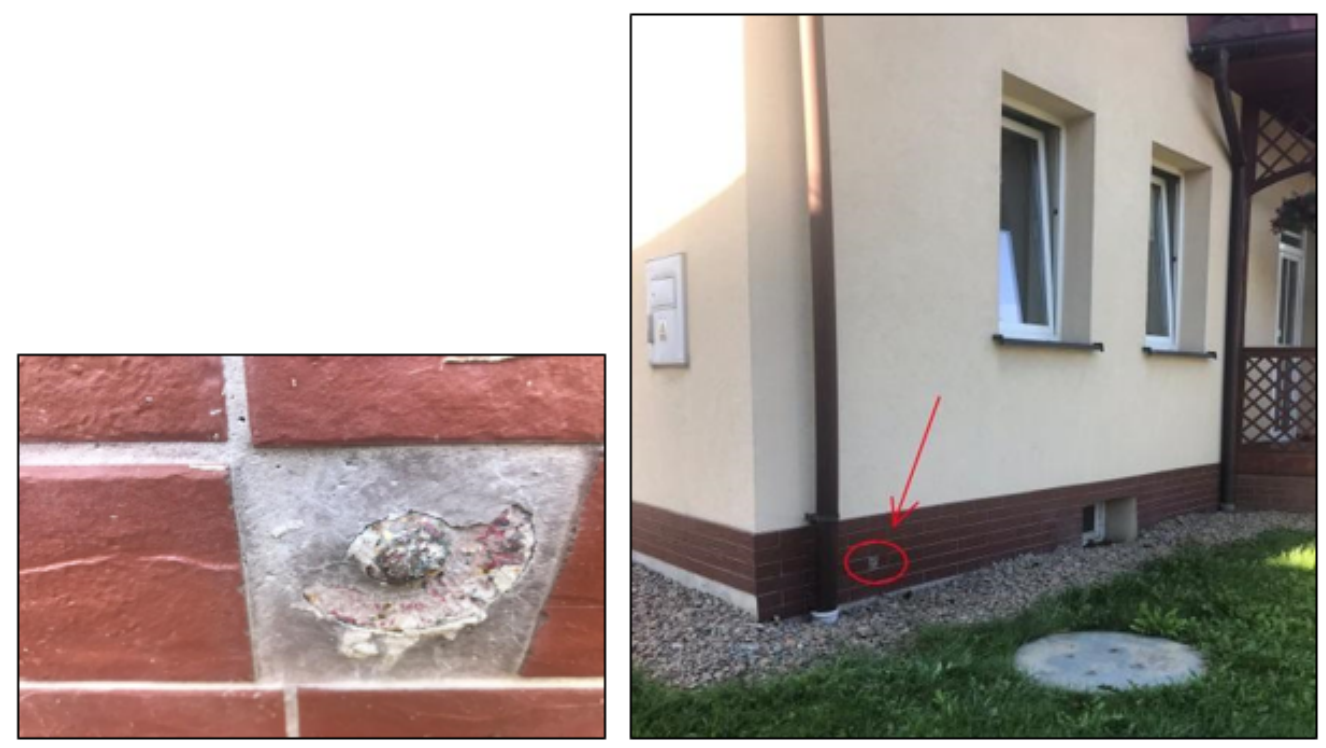

\section{Figure 21}

Photographs of destroyed point - Towns point location zone. Source: Authors' original contribution

\section{Supplementary Files}

This is a list of supplementary files associated with this preprint. Click to download.

- Table5.docx 